\title{
A NIR-II Fluorophore with Dithienylethene as the Electron Donor for Fluorescence/Photoacoustic Dual-Model Imaging and Photothermal Therapy
}

Jia Li,,$^{\dagger}$ Ruonan Wang,,$^{\dagger}$ Ying Sun,,$^{\dagger}$ Panpan Xiao,,$^{\dagger}$ Shuo Yang, ${ }^{\dagger}$ Xin Wang, ${ }^{\dagger}$ Quli Fan,,${ }^{+}$ Wei $W u,{ }^{*},+$ and Xiqun Jiang ${ }^{\dagger}$

$\dagger$ Department of Polymer Science \& Engineering, College of Chemistry \& Chemical Engineering, Nanjing University, Nanjing 210023, P. R. China.

†Key Lab Organ Elect \& Informat Displays, Nanjing University Posts \& Telecommun, Nanjing 210023, P. R. China

* To whom correspondence should be addressed. 


\section{Experimental Section}

\subsection{Materials}

All reagents and solvents were obtained from commercial reagent companies (TCI, J\&K, and Sigma-Aldrich, etc.) and used as received without further purification. Dry tetrahydrofuran (THF) was obtained by distilling over sodium under argon. Dry N, Ndimethylformamide was purchased from J\&K. All air and moisture sensitive reactions were carried out in flame-dried glassware under an argon atmosphere. MCF-7 human breast adenocarcinoma cells, MCF-10A human breast epithelial cell lines, LX-2 human hepatic stellate cells, 4T1 murine mammary gland tumor cells, and murine hepatoma 22 (H22) cells were purchased from Shanghai Institute of Cell Biology (Shanghai, China).

\subsection{Characterization}

The nuclear magnetic resonance (NMR) spectra were recorded on a Bruker Avance III $400 \mathrm{MHz}$ NMR spectrometer and a Bruker Avance III HD 500 MHz NMR spectrometer. Chemical shifts were reported as $\delta$ in units of parts per million (ppm) relative to internal $\mathrm{CDCl} 3\left({ }^{1} \mathrm{H}, 7.26 \mathrm{ppm}\right.$ and $\left.{ }^{13} \mathrm{C}, 77.16 \mathrm{ppm}\right)$ and DMSO-d $6\left({ }^{1} \mathrm{H}, 2.50 \mathrm{ppm}\right.$ and ${ }^{13} \mathrm{C}, 39.52$ ppm). Mass spectra were measured on a MALDI-TOF mass spectrometer (ultraflex treme TOF/TOF, Bruker, Germany). UV-Vis-NIR absorption spectra were recorded on a UV spectrophotometer (UV-5300, Metash, Shanghai). Photoluminescence (PL) measurements were carried out on HORIBA Fluolog 3 spectrophotometer. Particle size distribution data were measured by a dynamic light scattering (DLS) particle size analyzer (Brookhaven, USA). Transmission electron microscope (TEM) observations were carried out on JEOL JEM-1101 microscope at an accelerating voltage of $80 \mathrm{kV}$. NIR-II fluorescence images were acquired on a home-built imaging scanner (readout noise: 100 electron r.m.s.; pixel number: $256 \times 319$; dark signal: 2000 electrons pixel $^{-1}$ $\mathrm{s}^{-1}$ ). MTT assays were measured on a microplate reader (CMax Plus, Molecular Devices, Shanghai). PA imaging was completed on Visualsonics (Vevo® LAZR, CAN). 


\subsection{Synthesis}

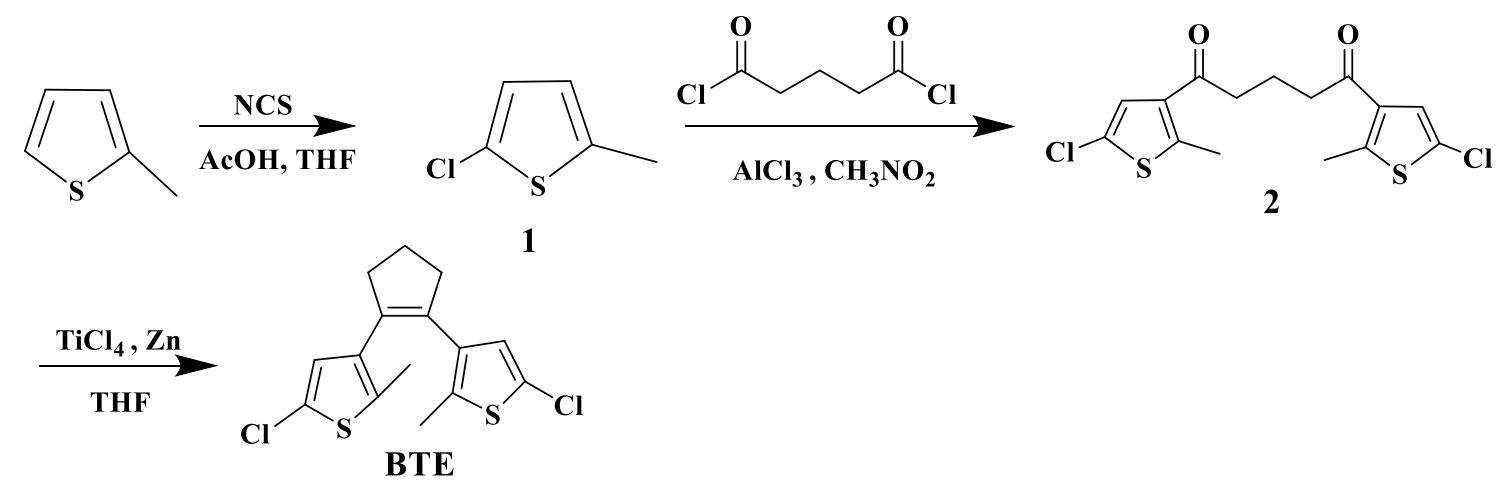

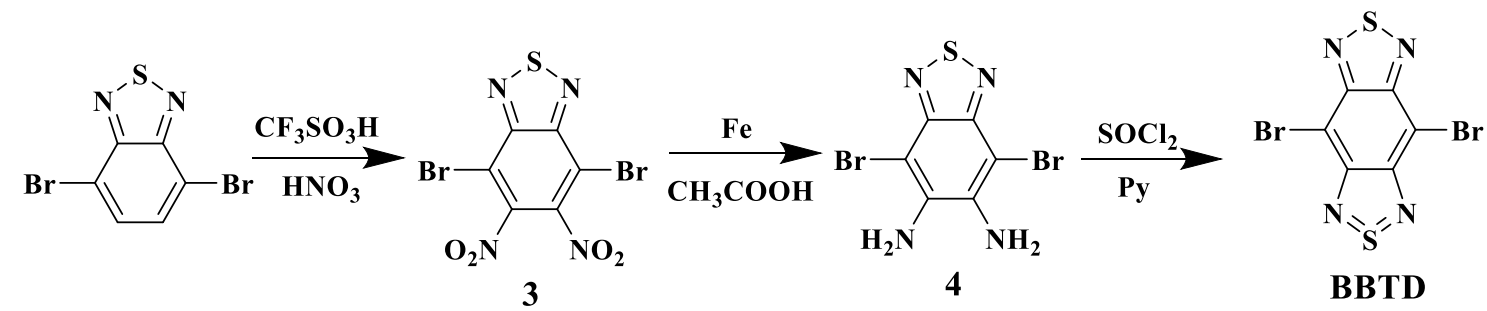

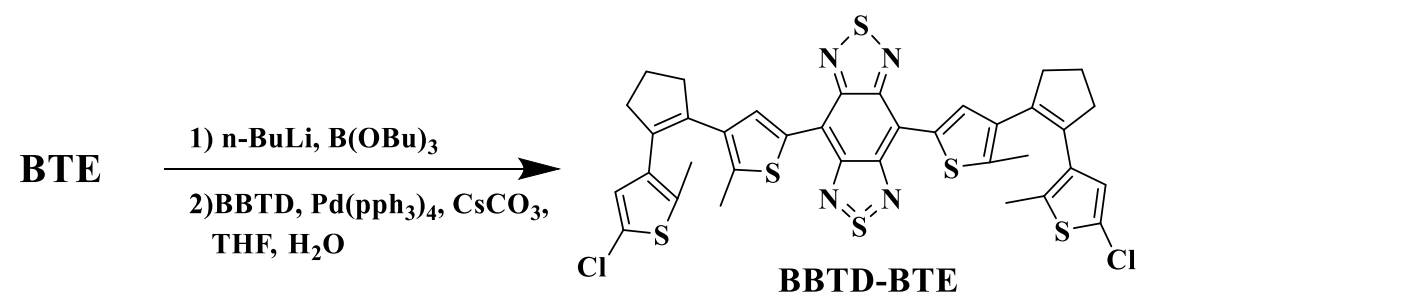

Synthesis of $\boldsymbol{B B T D}-\boldsymbol{B} T \boldsymbol{E}$.

\subsubsection{Synthesis of Compound 1}

2-Methylthiophene (50 mL, $0.516 \mathrm{~mol}), N$-chlorosuccinimide (NCS, $76 \mathrm{~g}, 0.569 \mathrm{~mol}$ ), and acetic acid $(200 \mathrm{~mL})$ were dissolved in $200 \mathrm{~mL}$ of THF. The resulting mixture was stirred at room temperature for $0.5 \mathrm{~h}$, and then under reflux for $4 \mathrm{~h}$. After cooling to room temperature, the mixture was poured into a $3 \mathrm{M} \mathrm{NaOH}$ solution $(300 \mathrm{~mL})$. The organic phase was washed with $3 \mathrm{M} \mathrm{NaOH}(3 \times 300 \mathrm{~mL})$ and dried over $\mathrm{Na}_{2} \mathrm{SO}_{4}$. After removal of the solvent under reduced pressure, the crude product was purified by vacuum distillation (19 Torr, $55^{\circ} \mathrm{C}$ ), affording a colorless liquid (60.2 g, yield: $88 \%$ ). ${ }^{1} \mathrm{H}$ NMR (400 MHz, $\left.\mathrm{CDCl}_{3}\right)$ ) 6.67 (d, 1H), 6.50 (dq, 1H), 2.39 (s, 3H).

${ }^{13} \mathrm{C}$ NMR $\left(101 \mathrm{MHz}, \mathrm{CDCl}_{3}\right) \delta: 138.51,126.54,125.81,124.41,15.47$. 


\subsubsection{Synthesis of Compound 2}

To a suspension of anhydrous $\mathrm{AlCl}_{3}(5.3 \mathrm{~g}, 39.5 \mathrm{mmol})$ in the nitromethane $(150 \mathrm{~mL})$ was added dropwise a mixture of compound 1 (5 g, $37.7 \mathrm{mmol})$ and glutaryl chloride $(3 \mathrm{~g}, 17.95 \mathrm{mmol})$ at $0{ }^{\circ} \mathrm{C}$. The resulting mixture was stirred at room temperature for 4 $\mathrm{h}$ and then poured into $50 \mathrm{~mL}$ of $20 \% \mathrm{HCl}$ aqueous solution in an ice water bath. The crude product was extracted with methylene chloride (DCM). The solution was further washed with $\mathrm{NaCl}$ saturated solution and dried over $\mathrm{Na}_{2} \mathrm{SO}_{4}$. After removal of the solvent, the crude product was purified by column chromatography with an eluant of petroleum ether (PE)/ethyl acetate (EA) (10:1) to provide a white solid (2.49 g, yield: $38.5 \%)$.

${ }^{1} \mathrm{H}$ NMR (400 MHz, $\left.\mathrm{CDCl}_{3}\right) \delta: 7.18(\mathrm{~s}, 2 \mathrm{H}), 2.86(\mathrm{t}, 4 \mathrm{H}), 2.66(\mathrm{~s}, 6 \mathrm{H}), 2.06(\mathrm{p}, 2 \mathrm{H})$.

${ }^{13} \mathrm{C}$ NMR $\left(101 \mathrm{MHz}, \mathrm{CDCl}_{3}\right) \delta: 194.86,147.71,134.90,126.83,125.32,40.52,18.17$, 16.02 .

\subsubsection{Synthesis of Compound BTE}

Zn powder (6 g, $91.7 \mathrm{mmol})$ was dispersed in $100 \mathrm{~mL}$ of dry THF and stirred in an ice water bath for $0.5 \mathrm{~h}$. Thereafter, $\mathrm{TiCl}_{4}(3.2 \mathrm{~mL}, 26.5 \mathrm{mmol})$ was cautiously added by syringe under $\mathrm{N}_{2}$ atmosphere and stirred at room temperature for $0.5 \mathrm{~h}$ and at $80{ }^{\circ} \mathrm{C}$ for $1 \mathrm{~h}$. After cooling to room temperature, compound $2(4 \mathrm{~g}, 11.0 \mathrm{mmol})$ was added and stirred at $80{ }^{\circ} \mathrm{C}$ for $4 \mathrm{~h}$. After cooling to room temperature again, a few drops of saturated aq. $\mathrm{NH}_{4} \mathrm{Cl}$ was added slowly. The resulting mixture was then extracted with diethyl ether. The solution was washed with water and dried over $\mathrm{Na}_{2} \mathrm{SO}_{4}$. After removal of the solvent, the crude product was purified by column chromatography with an eluant of PE to provide a white solid (2.69 g, yield: $74.3 \%)$.

${ }^{1} \mathrm{H}$ NMR (400 MHz, DMSO-d $)$ ) 6.83 (s, 2H), 2.71 (t, 4H), 1.97 (dd, 2H), 1.85 (s, $6 \mathrm{H})$.

${ }^{13} \mathrm{C}$ NMR (101 MHz, DMSO-d 6 ) $\delta: 135.41,134.55,133.55,127.71,124.16,38.25$, 22.64, 14.21. 


\subsubsection{Synthesis of Compound 3}

$42 \mathrm{~mL}$ of fuming nitric acid was added dropwise into $28 \mathrm{~mL}$ of trifluoromethanesulfonic acid in an ice water bath. The resulting mixture was stirred for $1 \mathrm{~h}$ and 4, 7dibromobenzo[c] $[1,2,5]$ thiadiazole $(8.24 \mathrm{~g}, 28.0 \mathrm{mmol})$ was added portion-wise over $1 \mathrm{~h}$ at $0{ }^{\circ} \mathrm{C}$. Thereafter, the resulting mixture was stirred at $50{ }^{\circ} \mathrm{C}$ for another $24 \mathrm{~h}$. After cooling to room temperature, the mixture was poured into $500 \mathrm{~mL}$ of ice-water mixture. The produced precipitate was collected by filtration and washed with water several times. The crude product was further purified by column chromatography on silica gel (PE: DCM = 1:2) to provide a yellow solid (11 g, yield: 70\%).

${ }^{13} \mathrm{C}$ NMR (101 MHz, DMSO-d 6 ) $\delta: 151.54,143.67,111.40$.

\subsubsection{Synthesis of Compound 4}

Compound 3 (10 g, $26.04 \mathrm{mmol})$ and iron powder (14.6 g, $260 \mathrm{mmol})$ were dispersed in $350 \mathrm{~mL}$ of acetic acid and the mixture was stirred at $80{ }^{\circ} \mathrm{C}$ for $6 \mathrm{~h}$. After cooling to room temperature, the mixture was poured into $1000 \mathrm{~mL}$ of ice-water mixture. The produced precipitate was collected by filtration and washed with water several times. After dried under vacuum, the product was recrystallized in ethanol and obtained as a yellow powder ( $8.1 \mathrm{~g}$, yield: $84 \%$ ).

${ }^{1} \mathrm{H}$ NMR (400 MHz, DMSO-d $) \delta: 6.35$ (s, 2H).

${ }^{13} \mathrm{C}$ NMR (101 MHz, DMSO-d 6 ) $\delta: 147.82,139.98,88.51$.

\subsubsection{Synthesis of Compound BBTD}

To a solution of Compound 4 ( $2 \mathrm{~g}, 6.16 \mathrm{mmol})$ in anhydrous chloroform $(60 \mathrm{~mL})$ was added thionyl chloride $(5.4 \mathrm{~mL})$ and anhydrous pyridine $(10.0 \mathrm{~mL})$ at $0{ }^{\circ} \mathrm{C}$. The resulting solution was stirred at $80{ }^{\circ} \mathrm{C}$ for $24 \mathrm{~h}$. Thereafter, the reaction mixture was allowed to cool to room temperature and poured into an ice water mixture. The resulting precipitate was collected by filtration and washed with dilute $\mathrm{HCl}$, water, and methanol to give a maroon solid (280 mg, yield: $68 \%$ ). 
MALDI-TOF-MS (m/z): Calcd for $\mathrm{C}_{6} \mathrm{Br}_{2} \mathrm{~N}_{4} \mathrm{~S}_{2}, 351.79$; found, 351.75 for $[\mathrm{M}]^{+}$.

\subsubsection{Synthesis of Compound BBTD-BTE}

BTE (200 mg, $0.6 \mathrm{mmol}$ ) was dissolved in dry and degassed THF (4 mL) and n-BuLi $(0.36 \mathrm{~mL}$ of $2.5 \mathrm{M}$ solution in hexane, $0.9 \mathrm{mmol})$ was added slowly by syringe at $0{ }^{\circ} \mathrm{C}$ under nitrogen. The mixture was stirred at room temperature for $30 \mathrm{~min}$ and $\mathrm{B}(\mathrm{OBu})_{3}$ $(0.17 \mathrm{~mL}, 0.6 \mathrm{mmol})$ was added. The resulting solution was stirred at room temperature for $2 \mathrm{~h}$ and was directly used in the following Suzuki cross-coupling reaction without further workup. BBTD (85 mg, $0.24 \mathrm{mmol}$ ) was dissolved in dry and degassed THF $(120 \mathrm{~mL})$, and $\mathrm{Pd}\left(\mathrm{PPh}_{3}\right)_{4}(70 \mathrm{mg}, 0.06 \mathrm{mmol})$ was added under nitrogen followed by stirring at room temperature for $10 \mathrm{~min}$. To the resulting solution, the first solution was added slowly by syringe followed by the addition of $\mathrm{Cs}_{2} \mathrm{CO}_{3}(1.18 \mathrm{~g}, 3.6 \mathrm{mmol})$ in 10 $\mathrm{mL}$ of water and $0.5 \mathrm{~mL}$ of ethylene glycol. This two-phase system was stirred under reflux for $24 \mathrm{~h}$. After removal of the solvent, $100 \mathrm{~mL}$ of dichloromethane (DCM) was added. The resulting solution was washed with $\mathrm{NaCl}$ saturated solution 3 times and dried over $\mathrm{Na}_{2} \mathrm{SO}_{4}$. The crude product was purified by column chromatography on silica gel $(\mathrm{PE} / \mathrm{DCM}=5: 1)$ to provide an aquamarine solid (11 $\mathrm{mg}$, yield: $5 \%)$

${ }^{1} \mathrm{H}$ NMR (500 MHz, $\left.\mathrm{CDCl}_{3}\right) \delta: 8.70(\mathrm{~s}, 2 \mathrm{H}), 6.72(\mathrm{~s}, 2 \mathrm{H}), 2.97(\mathrm{t}, 4 \mathrm{H}), 2.86-2.76(\mathrm{~m}$, 4H), $2.18(\mathrm{~s}, 6 \mathrm{H}), 2.13(\mathrm{p}, 4 \mathrm{H}), 1.94(\mathrm{~s}, 6 \mathrm{H})$.

${ }^{13} \mathrm{C} \mathrm{NMR}\left(126 \mathrm{MHz}, \mathrm{CDCl}_{3}\right) \delta: 151.18,141.39,136.91,135.47,134.42,134.33,133.88$, $133.48,127.06,125.30,113.00,38.64,38.57,23.14,14.78,14.40$.

MALDI-TOF-MS (m/z): Calcd for $\mathrm{C}_{36} \mathrm{H}_{28} \mathrm{Cl}_{2} \mathrm{~N}_{4} \mathrm{~S}_{6}, 778.00$; found: 778.2384 for $[\mathrm{M}]^{+}$. 

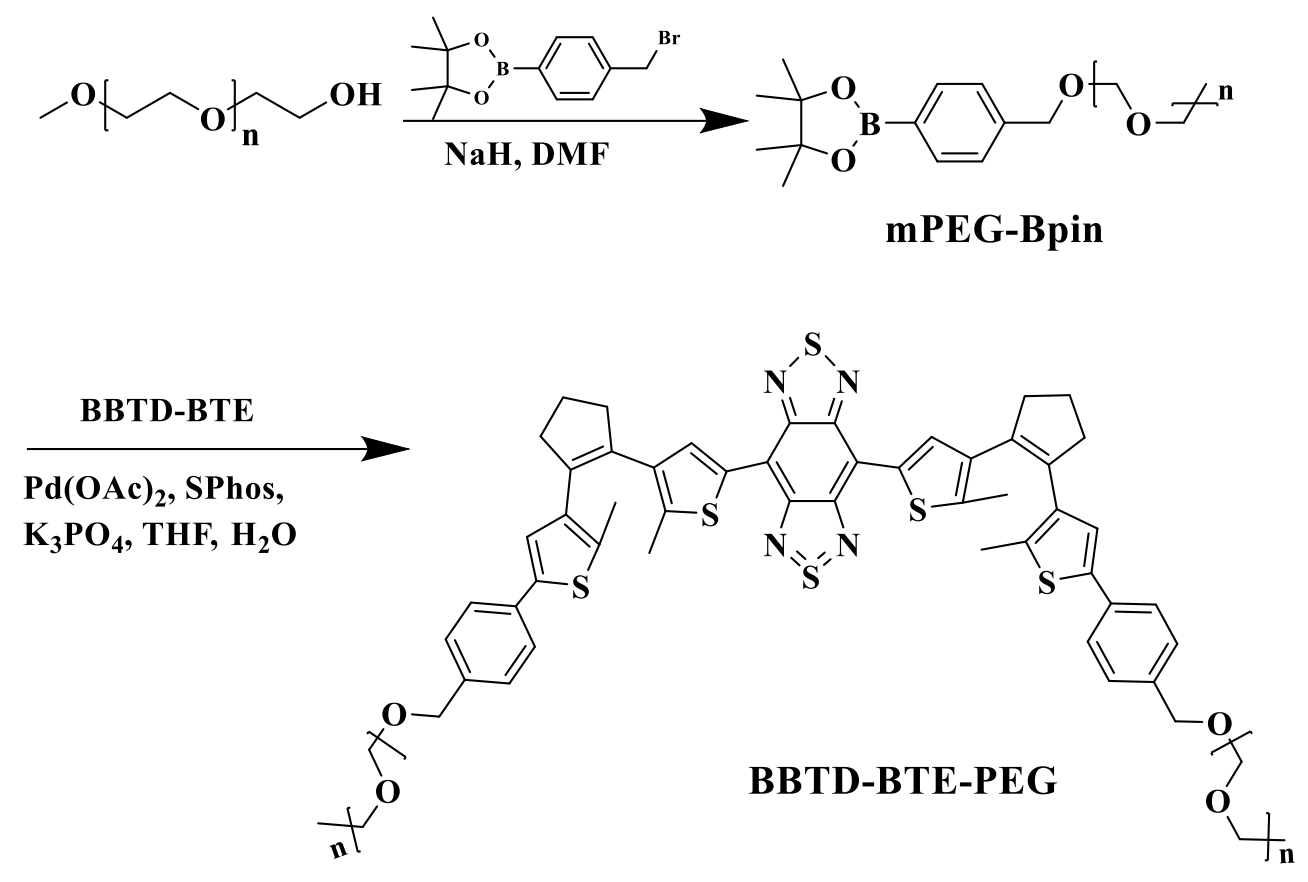

Synthesis of BBTD-BTE-PEG.

\subsubsection{Synthesis of Compound mPEG-Bpin}

To a solution of methoxypolyethylene glycols (mPEG, $2 \mathrm{KDa})(1 \mathrm{~g}, 0.5 \mathrm{mmol})$ in dry THF $(2 \mathrm{~mL})$ was added $\mathrm{NaH}(0.12 \mathrm{~g}, 5 \mathrm{mmol})$. The resulting mixture was stirred at $70{ }^{\circ} \mathrm{C}$ for $4 \mathrm{~h}$. A solution of 2-(4-bromophenyl)-4,4,5,5-tetramethyl-1,3,2dioxaborolane ( $1.49 \mathrm{~g}, 5 \mathrm{mmol})$ in $2 \mathrm{~mL}$ of dry THF was added, and stirred under reflux for $36 \mathrm{~h}$. After removal of the solvent, the product was precipitated from DCM to diethyl ether 3 times and dried under vacuum to give a white flocculent solid $(0.94 \mathrm{~g}$, yield: $84.64 \%)$.

1H NMR (400 MHz, $\left.\mathrm{CDCl}_{3}\right)$ ) $7.76(\mathrm{~d}, 1 \mathrm{H}), 7.33(\mathrm{~d}, 1 \mathrm{H}), 4.57(\mathrm{~s}, 1 \mathrm{H}), 3.62(\mathrm{~s}, 125 \mathrm{H})$, $3.37(\mathrm{~s}, 1.7 \mathrm{H}), 1.33(\mathrm{~s}, 6 \mathrm{H})$.

\subsubsection{Synthesis of Compound BBTD-BTE-PEG}

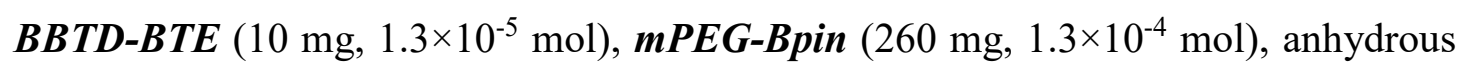
$\mathrm{K}_{3} \mathrm{PO}_{4}\left(16.5 \mathrm{mg}, 7.8 \times 10^{-5} \mathrm{~mol}\right)$, 2-dicyclohexylphosphino-2',6'-dimethoxybiphenyl (Sphos, $\left.1.07 \mathrm{mg}, 2.6 \times 10^{-6} \mathrm{~mol}\right)$, palladium (II) acetate $\left(0.58 \mathrm{mg}, 2.6 \times 10^{-6} \mathrm{~mol}\right)$, dry THF $(10 \mathrm{~mL})$, and $\mathrm{H}_{2} \mathrm{O}(0.2 \mathrm{~mL})$ were added into a $25 \mathrm{~mL}$ Schlenk flask. The flask was 
degassed by three freeze-pump-thaw cycles and backfilled with argon. The resulting mixture was stirred at $70{ }^{\circ} \mathrm{C}$ for $36 \mathrm{~h}$. After removal of the solvent, $10 \mathrm{~mL}$ of DCM was added. The solution was filtered through neutral alumina. After condensed under reduced pressure, the product was precipitated from DCM to diethyl ether several times and further purified by size-exclusion chromatography (Sephadex G50) eluting with water to give pure BBTD-BTE-PEG (34 mg, yield: 56\%).

\subsection{Fluorescence and Quantum Yield Measurements}

Fluorescence spectra were recorded on a fluorescence spectrometer (HORIBA Fluolog 3) with InGaAs NIR detector. An $808 \mathrm{~nm}$ diode laser was used as the excitation source to acquire the emission spectrum in $850-1500 \mathrm{~nm}$ region at room temperature. After raw emission data was collected, the fluorescence spectra were further corrected accounting to the detector sensitivity profile. The fluorescence quantum yields of BBTD-BTE in toluene and BBTD-BTE-PEG in water were measured according to a published protocol. ${ }^{1}$ The dye IR 26 in dichloromethane (DCE) whose quantum yield is $0.05 \%$ was used as the reference sample. The integrated fluorescence intensities of IR 26 in DCE, BBTD in toluene, and BBTD-BTE-PEG in water were plotted against absorbance at $808 \mathrm{~nm}$ and fitted into a linear function. The quantum yields were calculated by using the following equation:

$$
Q Y_{(\text {sample })}=Q Y_{(\text {ref })} \times \frac{\text { slope }_{(\text {sample })}}{\text { slope }_{(\text {ref })}} \times\left(\frac{n_{(\text {sample })}}{n_{(\text {ref })}}\right)^{2}
$$

Where QY (sample) is the quantum yield of the test sample, QY (ref) is the quantum yield

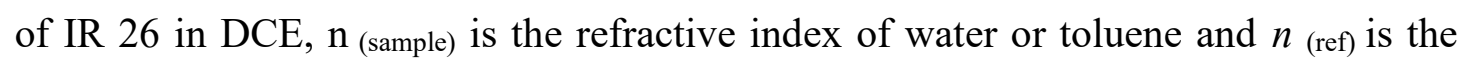
refractive index of DCE.

\subsection{CMC Measurement}

The CMC of BBTD-BTE-PEG was measured by using pyrene as a fluorescent probe. Pyrene $(4.05 \mathrm{mg}$ ) was dissolved in $100 \mathrm{~mL}$ of acetone serving as a stock solution. 10 $\mu \mathrm{L}$ of this stock solution was added to each $5 \mathrm{~mL}$ centrifuge tube. After the acetone volatilizes naturally at room temperature, $1 \mathrm{~mL}$ of the BBTD-BTE-PEG aqueous 
solution (the concentration ranges from 1 to $1000 \mathrm{mg} / \mathrm{L}$ ) was added. Then the mixture were sonicated for 10 minutes, and allowed to stand at room temperature for 24 hours, respectively. The fluorescence spectrum of each sample was measured with the excitation wavelength of $335 \mathrm{~nm}$ and the recorded wavelength range of $350-550 \mathrm{~nm}$.

\subsection{Theory Calculations}

Gaussian16 A03 GNU/Linux program was used to conduct all the quantum chemical calculations. ${ }^{2}$ Theoretical calculations were carried out using density functional theory (DFT) method at the B3LYP/6-31G(d) level of theory in toluene with solute electron density (SMD) solvent model. Vibrational frequency analysis was conducted to ensure that geometry optimizations had reached the local minimum. The HOMO and LUMO orbital surfaces were produced by GaussView 6.0.16.

\subsection{Photostability Test}

The solutions of BBTD-BTE-PEG in water, NS, PBS and FBS were irradiated continuously by an $808 \mathrm{~nm}$ laser at a power density of $200 \mathrm{~mW} / \mathrm{cm}^{2}$ for $1 \mathrm{~h}$, respectively. During this period, images were acquired at $5 \mathrm{~min}$ intervals $(980 \mathrm{~nm}$ long-pass filter (Semrock) and $100 \mathrm{~ms}$ exposure time) on a home-built imaging set-up with a 2D InGaAs camera, and the average fluorescence intensity of the region of interest was plotted as a function of time.

\subsection{Cytotoxicity}

Five types of cells were used to evaluate the in vitro cytotoxicity of BBTD-BTE-PEG: MCF-7 human breast adenocarcinoma cells, MCF-10A human breast epithelial cells, LX-2 human hepatic stellate cells, 4T1 murine mammary gland tumor cells, and murine hepatoma 22 (H22 cells).

For the adherent cell lines (MCF-7, MCF-10A and LX-2 cells), $100 \mu \mathrm{L}$ of cells were seeded in a 96-well plate at a density of $5 \times 10^{3}$ cells $/ \mathrm{mL}$ and incubated for $24 \mathrm{~h}$. Then the cells were treated with BBTD-BTE-PEG at different concentrations and co- 
incubated for another $24 \mathrm{~h}$. A $5.0 \mathrm{mg} / \mathrm{mL}$ stock solution of MTT was prepared in PBS and this stock solution $(10 \mu \mathrm{L})$ was added to each well. After additional $4 \mathrm{~h}$ incubation, the medium and MTT were removed, and the MTT-formazan crystals in each well were dissolved in $100 \mu \mathrm{L}$ of DMSO. The absorbance of the suspension was recorded by a microplate reader (CMax Plus, Molecular Devices, Shanghai) at a wavelength of 562 nm.

For the non-adherent $\mathrm{H} 22$ cell line, $100 \mu \mathrm{L}$ of cells were seeded in a 96-well plate at a density of $1 \times 10^{4}$ cells $/ \mathrm{mL}$ and incubated for $24 \mathrm{~h}$. Then the H22 cells were treated with BBTD-BTE-PEG $(100 \mu \mathrm{L})$ at different concentrations and co-incubated for another 24 h. $10 \mu \mathrm{L}$ of the $5.0 \mathrm{mg} / \mathrm{mL}$ stock solution of MTT was added to each well. After the cells were incubated for 4 hours, $100 \mu \mathrm{L}$ of the mixture $(10 \%$ SDS, $5 \%$ isobutanol, $0.012 \mathrm{~mol} / \mathrm{L} \mathrm{HCl}$, dissolved in distilled water) was added, and then incubated overnight. The absorbance of the suspension was recorded by a microplate reader at a wavelength of $562 \mathrm{~nm}$.

\subsection{Hemolysis}

Red blood cells (RBCs) were isolated by fresh blood centrifugation and washed three times with normal saline solution. In each hemolysis experiment, $2 \times 10^{8} \mathrm{RBCs}$ were suspended in $1 \mathrm{~mL}$ of PBS, followed by addition of $1 \mathrm{~mL}$ of a PBS solution of BBTDBTE-PEG with a pre-determined concentration. The mixture was incubated at $37{ }^{\circ} \mathrm{C}$ for $1 \mathrm{~h}$, and then centrifuged for $5 \mathrm{~min}$ at $3000 \mathrm{rpm}$ to separate the intact RBCs and disrupted membranes from the solution. The absorbance of the supernatant containing the released hemoglobin $(\mathrm{Hb})$ was then measured at $540 \mathrm{~nm}$. A $100 \%$ hemolysis as a positive control was determined by measuring the absorbance of $2 \times 10^{8} \mathrm{RBCs}$ with complete lysis by suspending them in deionized water. The negative control was $2 \times 10^{8}$ RBCs in PBS. Each hemolysis is reported as the average value of three repeated measurements. The hemolysis rate were calculated by using the following equation: 


$$
\operatorname{Hemolysis}(\%)=\frac{\left(A-A_{n}\right)}{\left(A_{p}-A_{n}\right)} \times 100 \%
$$

Where $A$ is the absorbance of the sample; $A_{n}$ is the absorbance of the negative control group; $A_{p}$ is the absorbance of the positive control group. When the hemolysis rate was more than $5 \%$, the materials could be judged to have hemolytic effect.

\subsection{Blood Circulation Half-life Measurement}

After tail-vein injection of a BBTD-BTE-PEG solution $(10 \mathrm{mg} / \mathrm{mL}, 200 \mu \mathrm{L})$ into $\mathrm{H} 22$ tumor-bearing mice, the blood samples were acquired from eye puncture at different time points and centrifuged at $3000 \mathrm{rpm}$ for $15 \mathrm{~min}$. The fluorescence intensities of the plasm samples were measured by using a fluorescence spectrometer (HORIBA Fluolog 3) with an $808 \mathrm{~nm}$ laser excitation. The plasm concentrations of BBTD-BTE-PEG were calculated based on a calibration curve, which was established by adding predetermined amounts of BBTD-BTE-PEG to the plasm taken from untreated mice, measuring the fluorescence intensities of the resulting mixtures and creating the plot of the fluorescence intensity versus plasma concentration.

\subsection{In Vitro Cytotoxicity in PTT Studies}

$100 \mu \mathrm{L}$ of $\mathrm{H} 22$ cells were seeded in a 96 -well plate at a density of $1 \times 10^{4}$ cells $/ \mathrm{mL}$ and incubated for $24 \mathrm{~h}$. Then the cells were treated with BBTD-BTE-PEG (100 $\mu \mathrm{L})$ at different concentrations and co-incubated for another $24 \mathrm{~h}$. The cells were divided into two groups: one was irradiated with an $808 \mathrm{~nm}$ laser $\left(0.3 \mathrm{~W} / \mathrm{cm}^{2}\right)$ for $5 \mathrm{~min}$, the other was not exposed to any treatments. The resulting cells were incubated for another $24 \mathrm{~h}$ and studied by MTT assay.

\subsection{In Vitro Photothermal Property Study}

A series of BBTD-BTE-PEG aqueous solutions with different concentrations were irradiated by the $808 \mathrm{~nm}$ laser with different power densities, respectively. The 
temperatures of these solutions were measured at predetermined time points. In the study of photothermal stability, the BBTD-BTE-PEG solutions were exposed to the 808 $\mathrm{nm}$ laser $\left(0.3 \mathrm{~W} / \mathrm{cm}^{2}\right)$ for $5 \mathrm{~min}$, respectively, and then the laser was removed, and the samples were allowed to cool naturally for $5 \mathrm{~min}$. The above procedures were repeated 5 times. The photothermal conversion efficiency is calculated by the previously reported method. ${ }^{3}$

\subsection{Animal Experiments}

All animal experiments were implemented according to the National Institute of Health Guide for the Care and Use of Laboratory Animals and approved by the Animal Ethics Committee of Drum Tower Hospital (Nanjing, China).

\subsubsection{Establishment of Tumor Models}

To establish H22 tumor models, H22 cells in physiological saline were injected into ICR mice (male, 18-22 g) at the abdomen. After 2 weeks, H22 cells were extracted directly from ascites, then diluted with physiological saline to a concentration of about $1 \times 10^{6} \mathrm{H} 22$ cells in $100 \mu \mathrm{L}$ of saline and injected subcutaneously to the BALB/c nude mice (female, 18-22 g) at the lateral thigh. When the tumors reached a mean volume of $\sim 150 \mathrm{~mm}^{3}$, the mice were subjected to imaging studies.

To establish 4T1 tumor models, 4T1 cells $\left(1 \times 10^{6}\right.$ cells in $200 \mu \mathrm{L}$ of PBS $)$ were injected subcutaneously into the lateral thigh of BALB/c nude mice (female, 18-22 g). When the tumors reached a mean volume of $\sim 150 \mathrm{~mm}^{3}$, the mice were subjected to imaging studies.

\subsubsection{In Vivo Fluorescence Imaging}

NIR-II fluorescence images were acquired by a home-built imaging setup with a 2D InGaAs camera. An $808 \mathrm{~nm}$ laser was used as the excitation source and a $980 \mathrm{~nm}$ longpass filter was used as the emission filter. The laser power density was set at $55 \mathrm{~mW} / \mathrm{cm}^{2}$. Fluorescence imaging was immediately performed after the mice were injected with the 
BBTD-BTE-PEG solution $(200 \mu \mathrm{L}, 6 \mathrm{mg} / \mathrm{mL})$ in PBS via tail vein. The exposure time was set as $2000 \mathrm{~ms}$ for vessel imaging and $200 \mathrm{~ms}$ for tumor imaging.

\subsubsection{Ex Vivo Biodistribution Analysis}

For ex vivo biodistribution analysis, the tumor-bearing mice were sacrificed at $108 \mathrm{~h}$ after tail-vein injection of the BBTD-BTE-PEG solution. The major organs, tissues and tumors were excised and imaged on the NIR-II imaging system $\left(200 \mathrm{~ms}, 55 \mathrm{~mW} / \mathrm{cm}^{2}\right.$, a $980 \mathrm{~nm}$ long-pass filter). The mean fluorescence intensity of each sample was obtained by dividing the total signal intensity by the area of the region of interest.

\subsubsection{In Vivo PA Imaging}

Each mouse was injected with $100 \mu \mathrm{L}$ of a BBTD-BTE-PEG solution $(10 \mathrm{mg} / \mathrm{mL})$ in normal saline via tail vein. Under a laser with a wavelength of $780 \mathrm{~nm}$, a $21 \mathrm{MHz}$ Vevo® LAZR system was used to scan the tumor area of the mouse at different time points.

\subsubsection{In Vivo PTT}

H22 tumor models were established according to the procedures described above. The tumor inhibition experiments were started when the tumors grew to about $100 \mathrm{~mm}^{3}$. H22 tumor-bearing mice were randomly divided into 4 groups: PBS, BBTD-BTE-PEG, PBS $+808 \mathrm{~nm}$ laser, BBTD-BTE-PEG $+808 \mathrm{~nm}$ laser, 8 mice in each group. On the $2^{\text {nd }}$ day after tail-vein injection of PBS $(200 \mu \mathrm{L})$ or BBTD-BTE-PEG $(200 \mu \mathrm{L}, 10$ $\mathrm{mg} / \mathrm{mL}$ ), the tumors were irradiated with an $808 \mathrm{~nm}$ laser for 10 minutes, and during the irradiation, the tumor temperature was monitored by using a thermal imaging camera.

After the different treatments, the relative tumor volumes and body weights of the mice were recorded every other day for 14 days. The tumor volume was calculated by using the equation: tumor volume $=1 / 2 \times$ length $\times$ width $^{2}$. 


\subsubsection{Blood Biochemistry and Histological Analysis}

On the $14^{\text {th }}$ day after the respective injection of BBTD-BTE-PEG PBS solution (10 $\mathrm{mg} / \mathrm{mL}, 200 \mu \mathrm{L})$ and PBS $(200 \mu \mathrm{L})$, the blood was sampled from eye puncture for the blood routine tests and blood biochemistry analysis. Then the main organs including liver, spleen, heart, lung and kidney were excised, fixed in $4 \%$ paraformaldehyde, embedded in paraffin, sectioned at a thickness of $5 \mu \mathrm{m}$, stained with $\mathrm{H} \& \mathrm{E}$, and examined with inverted optical microscopy. Three mice were used for each sample.

The blood test items included: white blood cell (WBC), red blood cell (RBC), hemoglobin (HGB), hematocrit (HCT), mean corpuscular volume (MCV), mean corpuscular hemoglobin $(\mathrm{MCH})$, mean corpuscular hemoglobin concentration (MCHC), red blood distribution width (RDW), and platelets (PLT). The blood biochemistry analysis items included: three important hepatic indicators (i.e. alanine aminotransferase (ALT), aspartateaminotransferase (AST), albumin (ALB)), three renal function-related indicators (i.e. urea nitrogen $(\mathrm{BUN})$, creatinine $(\mathrm{CR})$, uric acid (UA)), and tow myocardial enzymes indicators (i.e. lactic dehydrogenase (LDH), creatine kinase $(\mathrm{CK}))$. 


\section{Supplementary Figures}

年<smiles>Cc1ccc(Cl)s1</smiles>

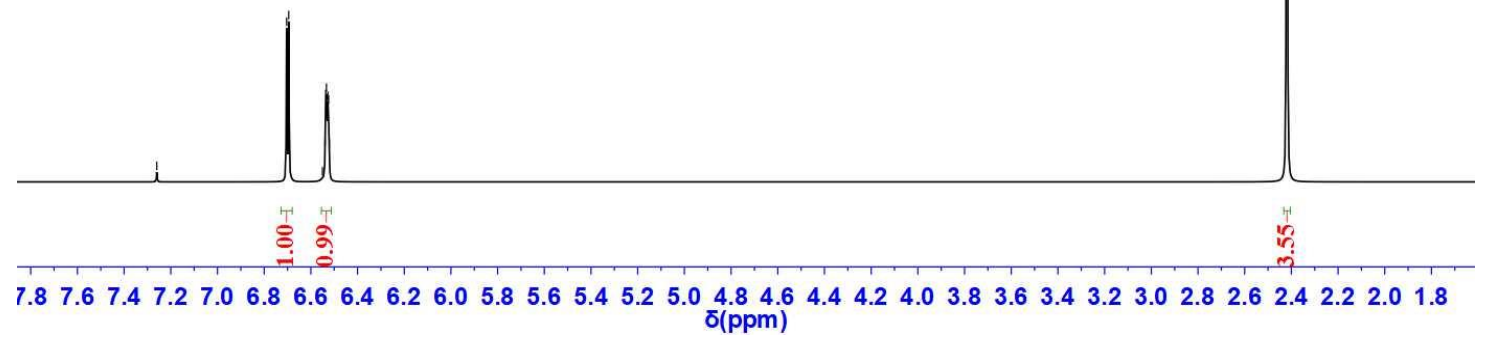

Figure S1. ${ }^{1} \mathrm{H}$ NMR spectrum of compound 1. (400 MHz, $\left.\mathrm{CDCl}_{3}\right)$
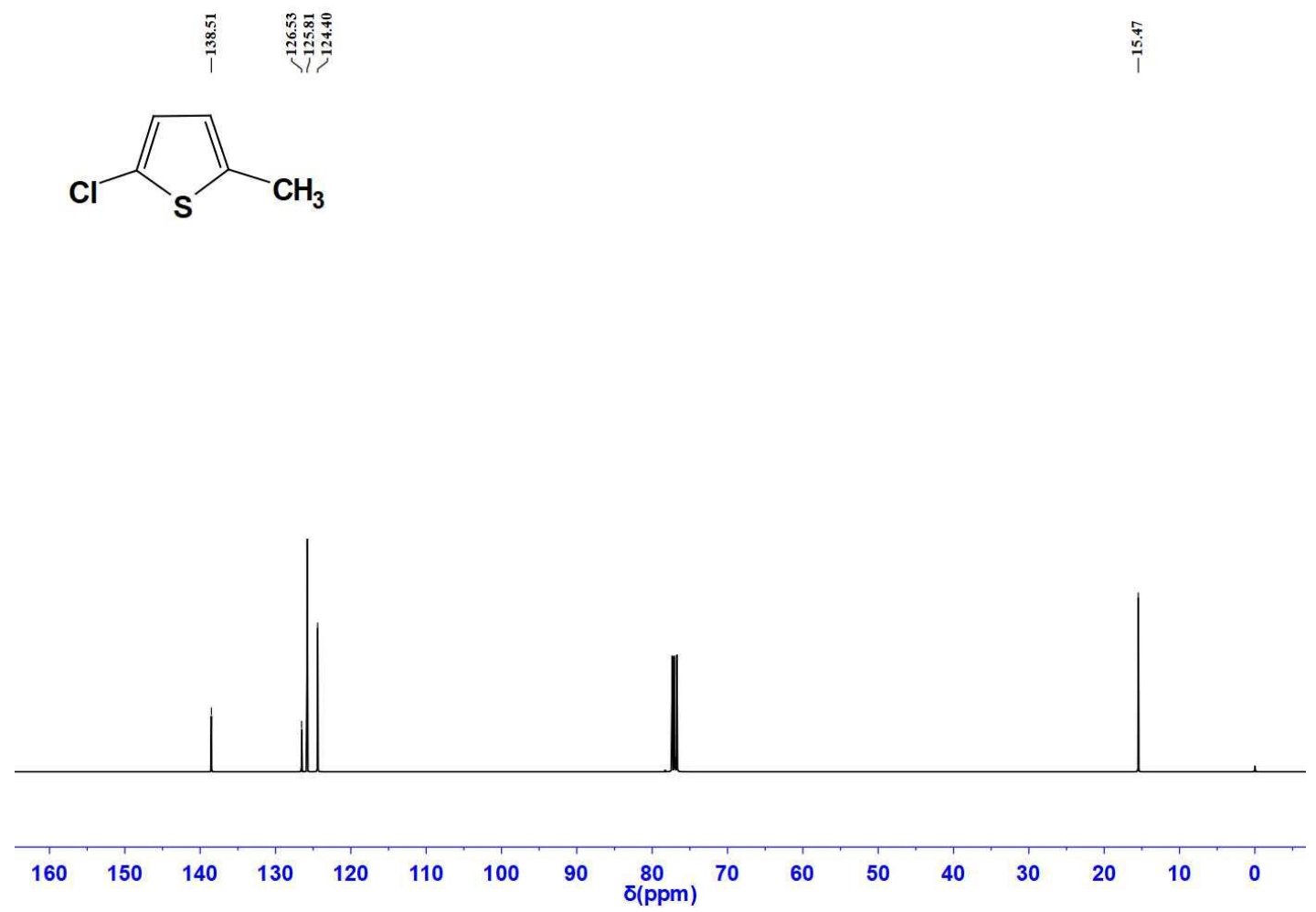

Figure S2. ${ }^{13} \mathrm{C}$ NMR spectrum of compound 1. (101 MHz, $\left.\mathrm{CDCl}_{3}\right)$ 

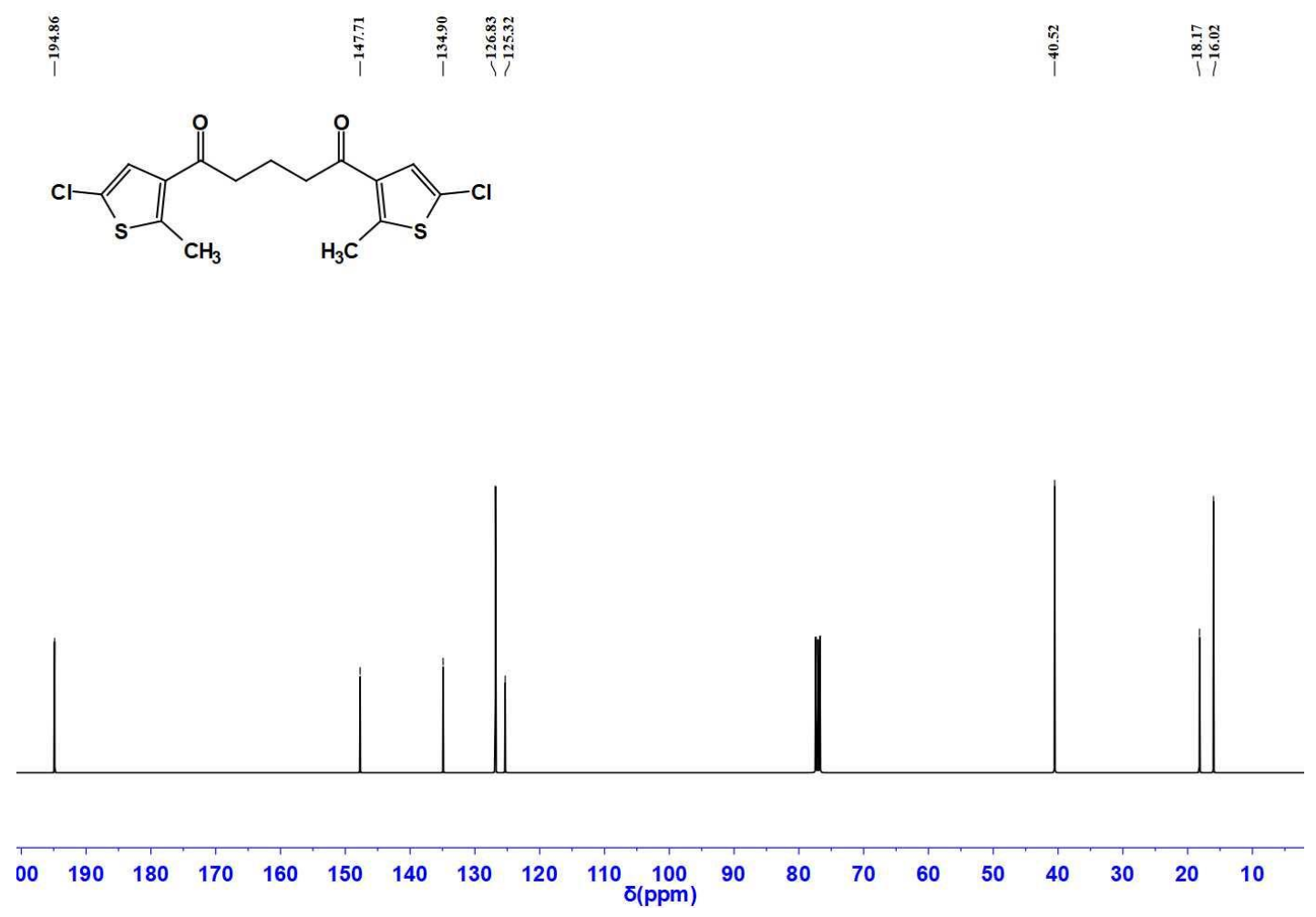

Figure S3. ${ }^{1} \mathrm{H}$ NMR spectrum of compound 2. (400 MHz, $\left.\mathrm{CDCl}_{3}\right)$<smiles>Cc1sc(Cl)cc1C(=O)CCCC(=O)c1cc(Cl)sc1C</smiles>
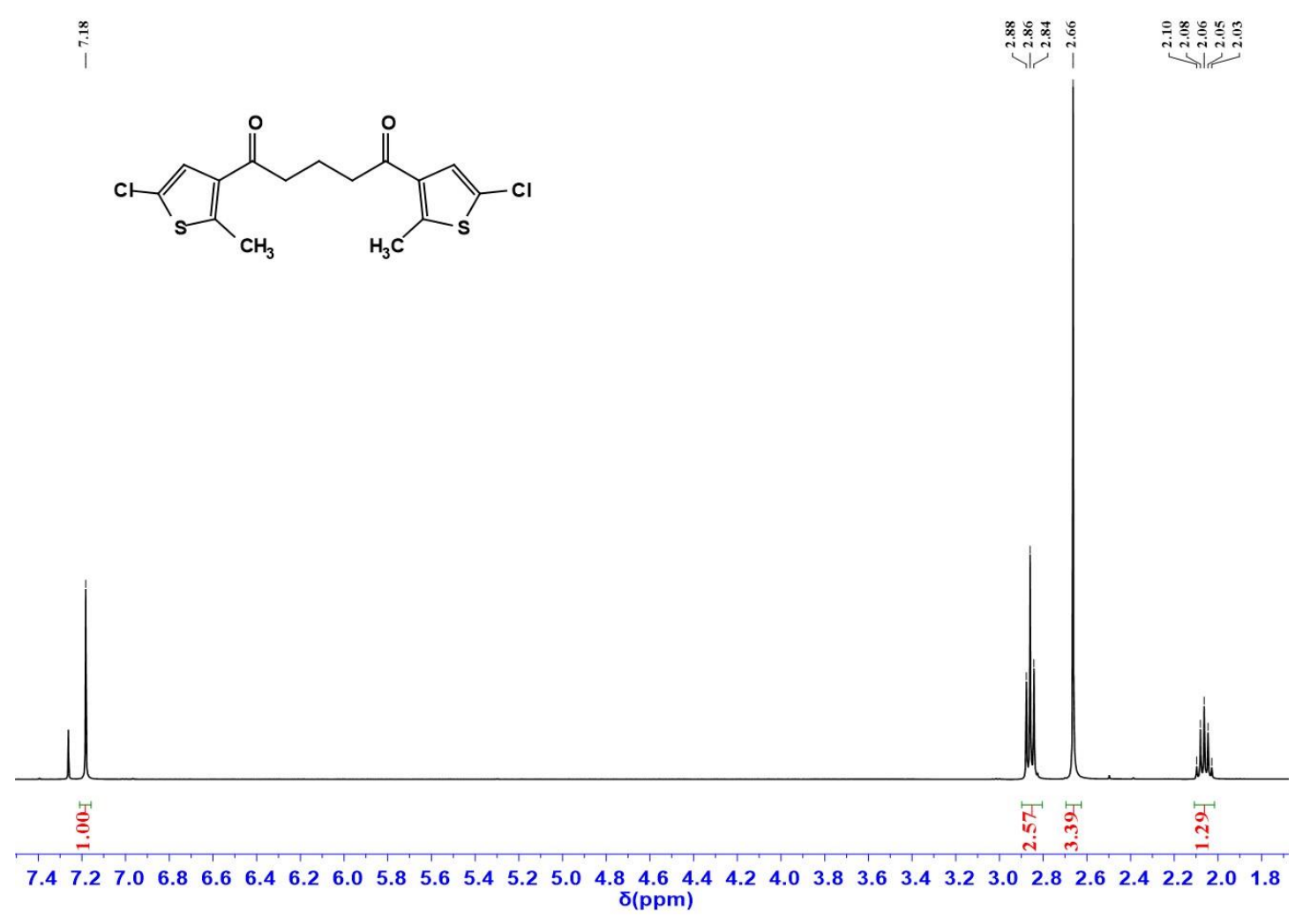

Figure S4. ${ }^{13} \mathrm{C}$ NMR spectrum of compound 2. (101 MHz, $\left.\mathrm{CDCl}_{3}\right)$ 


$$
\text { i }
$$
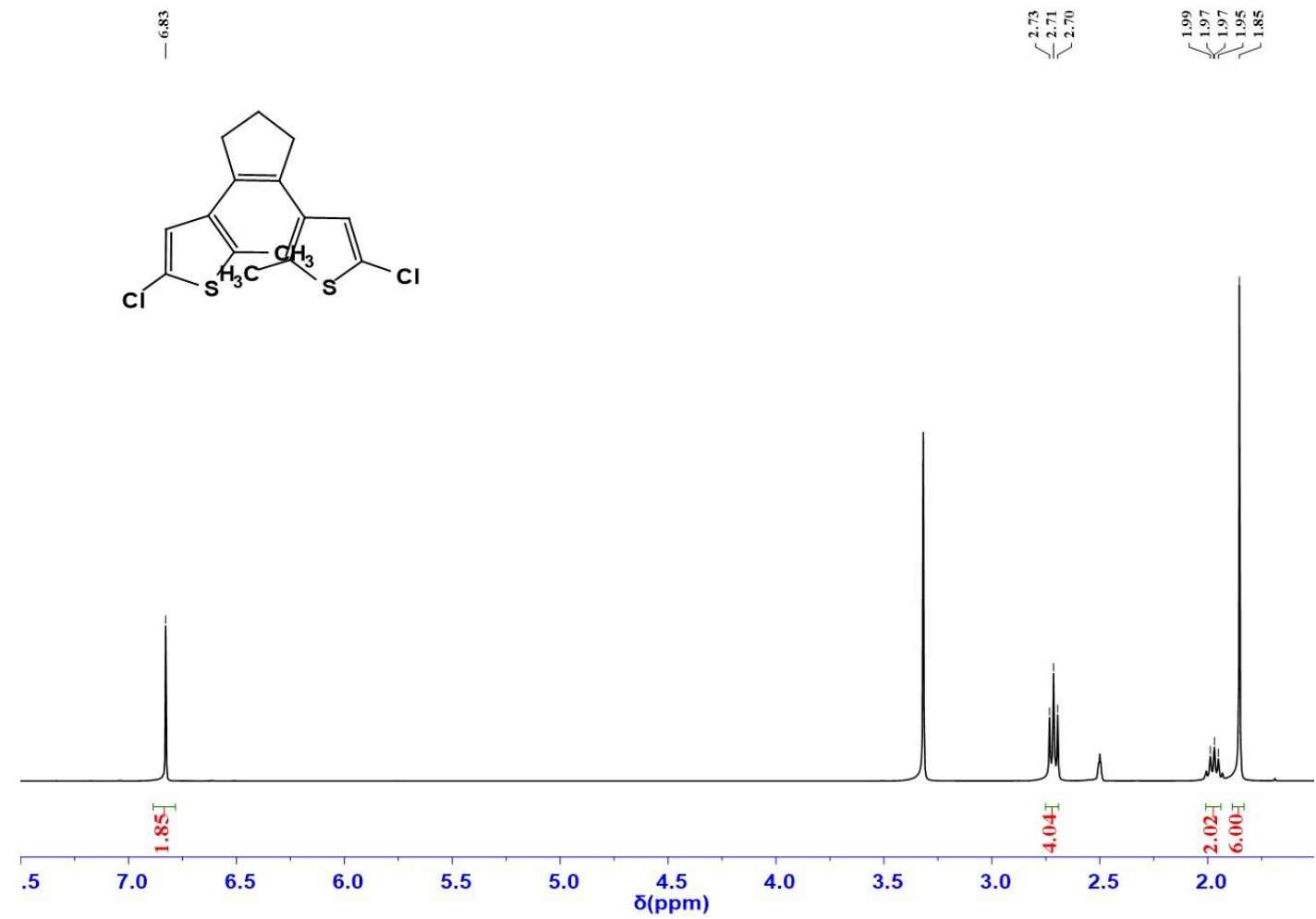

Figure S5. ${ }^{1} \mathrm{H}$ NMR spectrum of BTE. (400 MHz, DMSO-d $\left.{ }_{6}\right)$

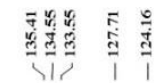
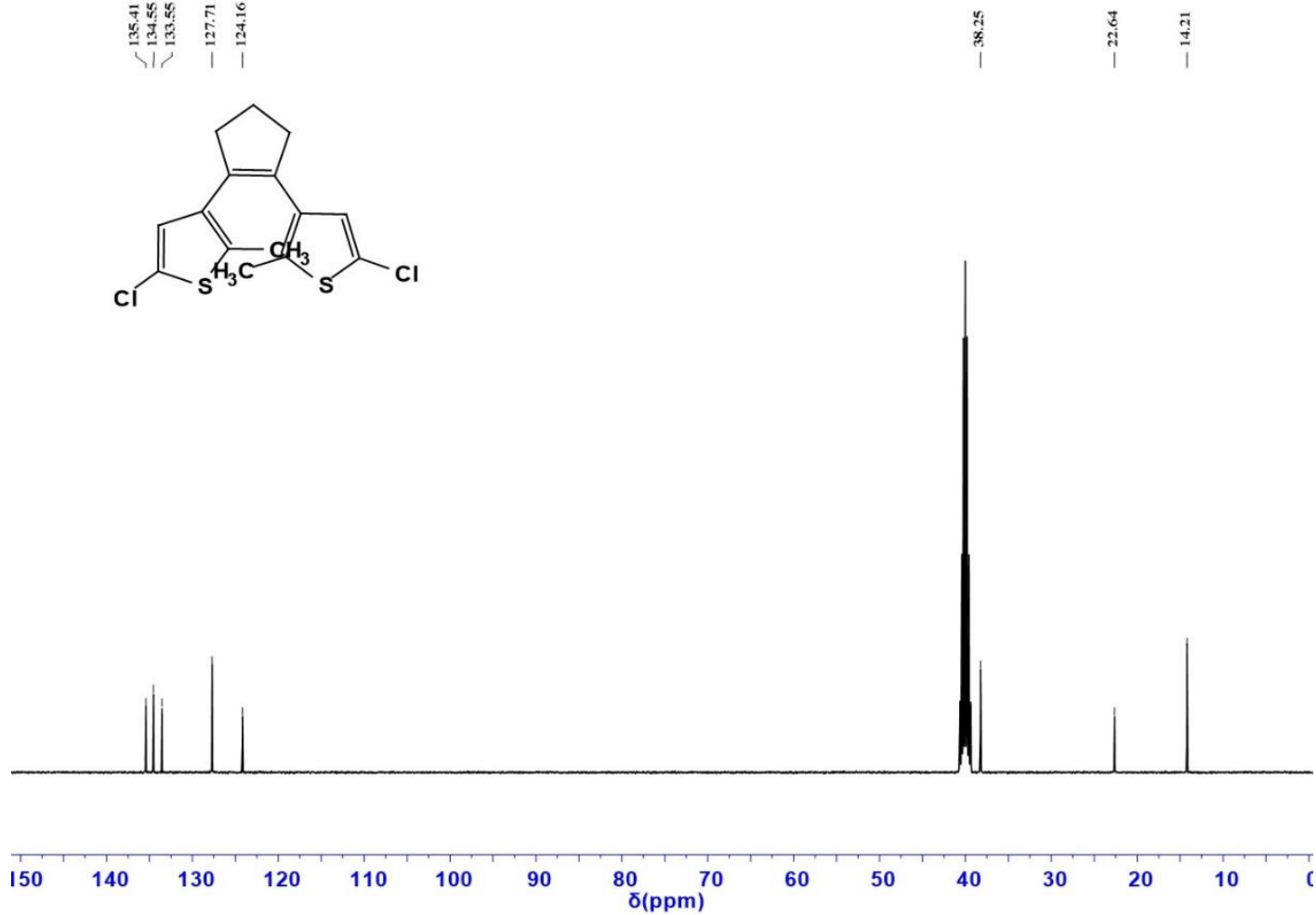

Figure S6. ${ }^{13} \mathrm{C}$ NMR spectrum of BTE. (101 MHz, DMSO-d $\left.{ }_{6}\right)$ 


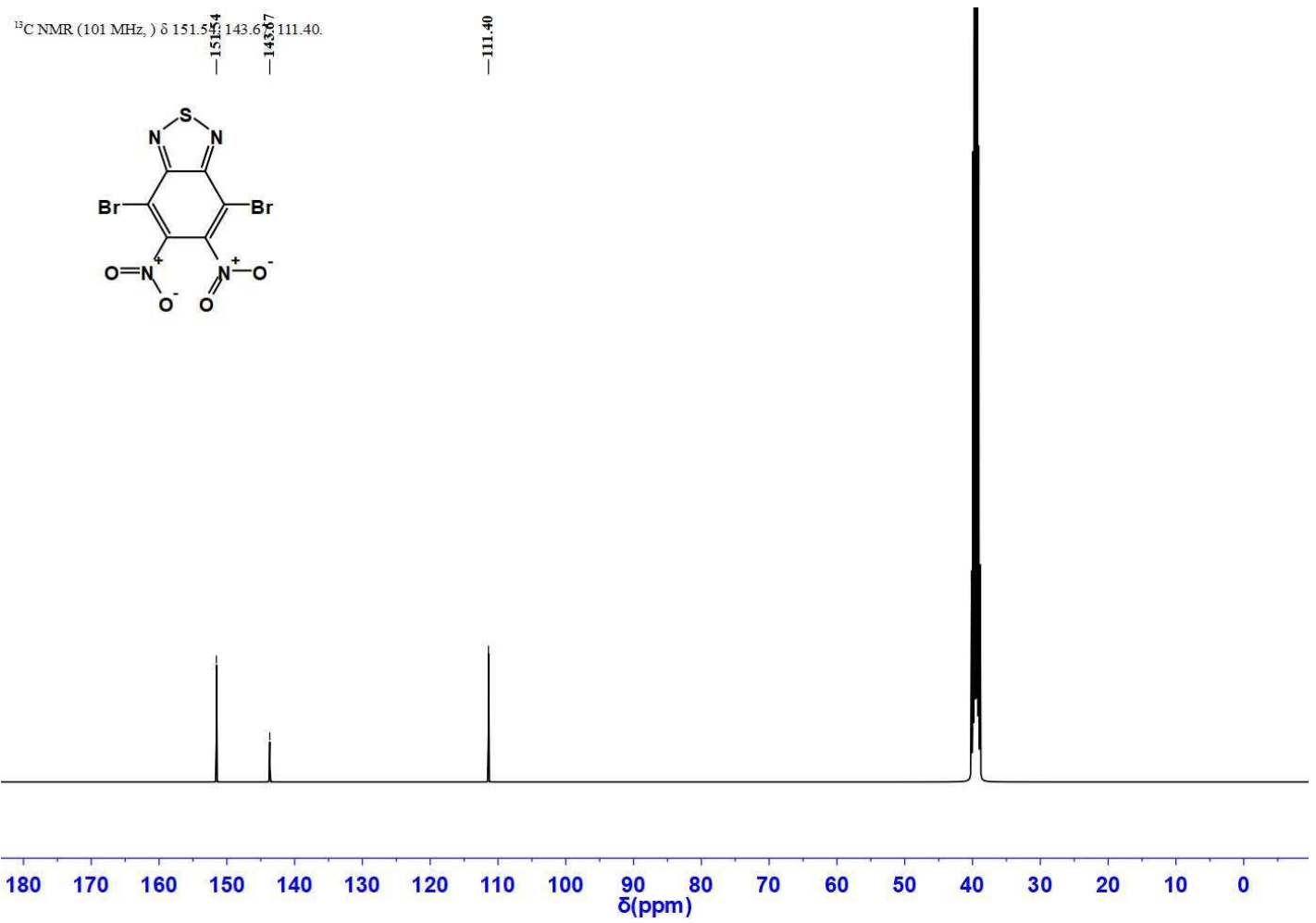

Figure S7. ${ }^{13} \mathrm{C}$ NMR spectrum of compound 3. (101 MHz, DMSO-d 6 )

ind
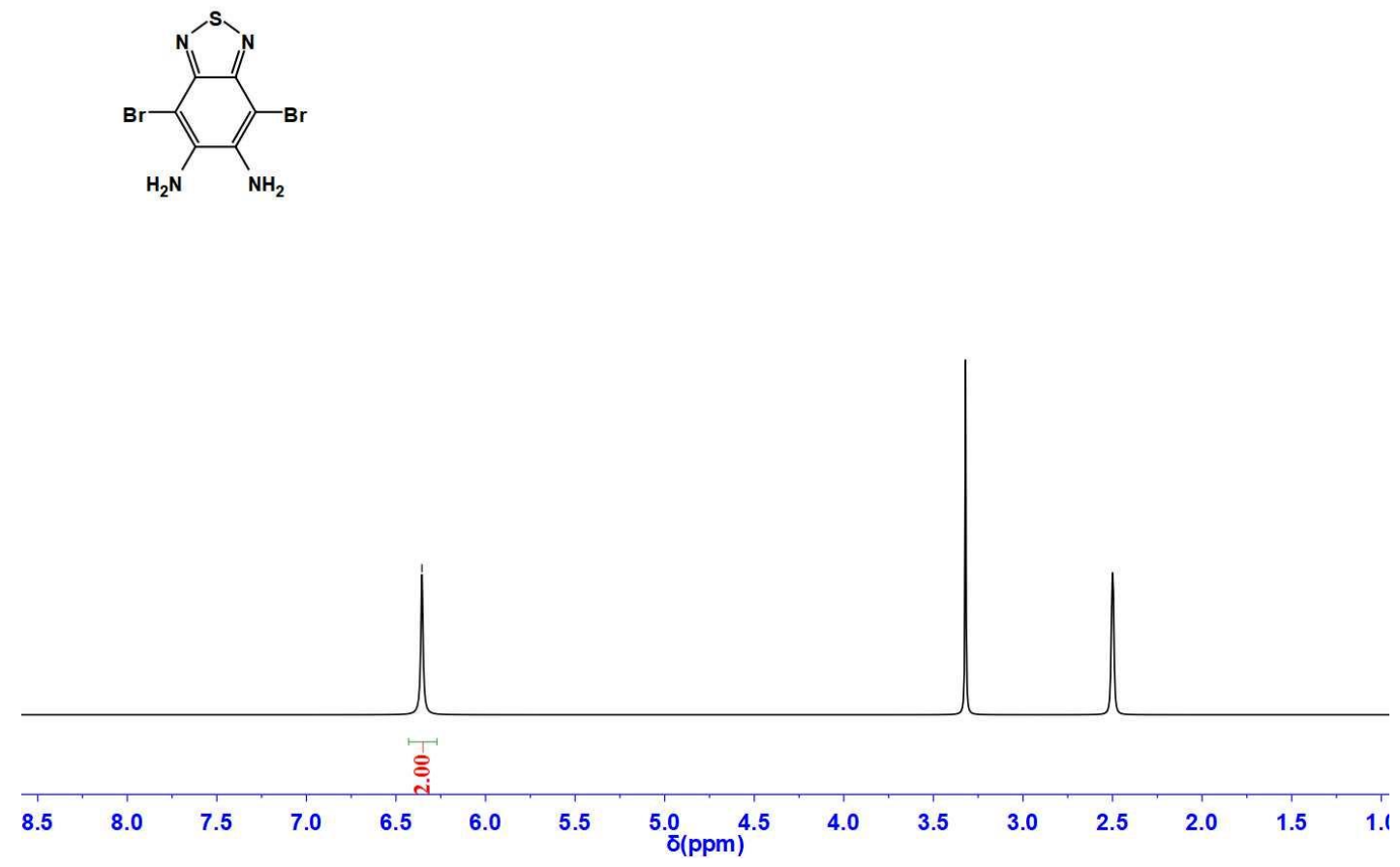

Figure S8. ${ }^{1} \mathrm{H}$ NMR spectrum of compound 4. (400 MHz, DMSO-d 6 ) 


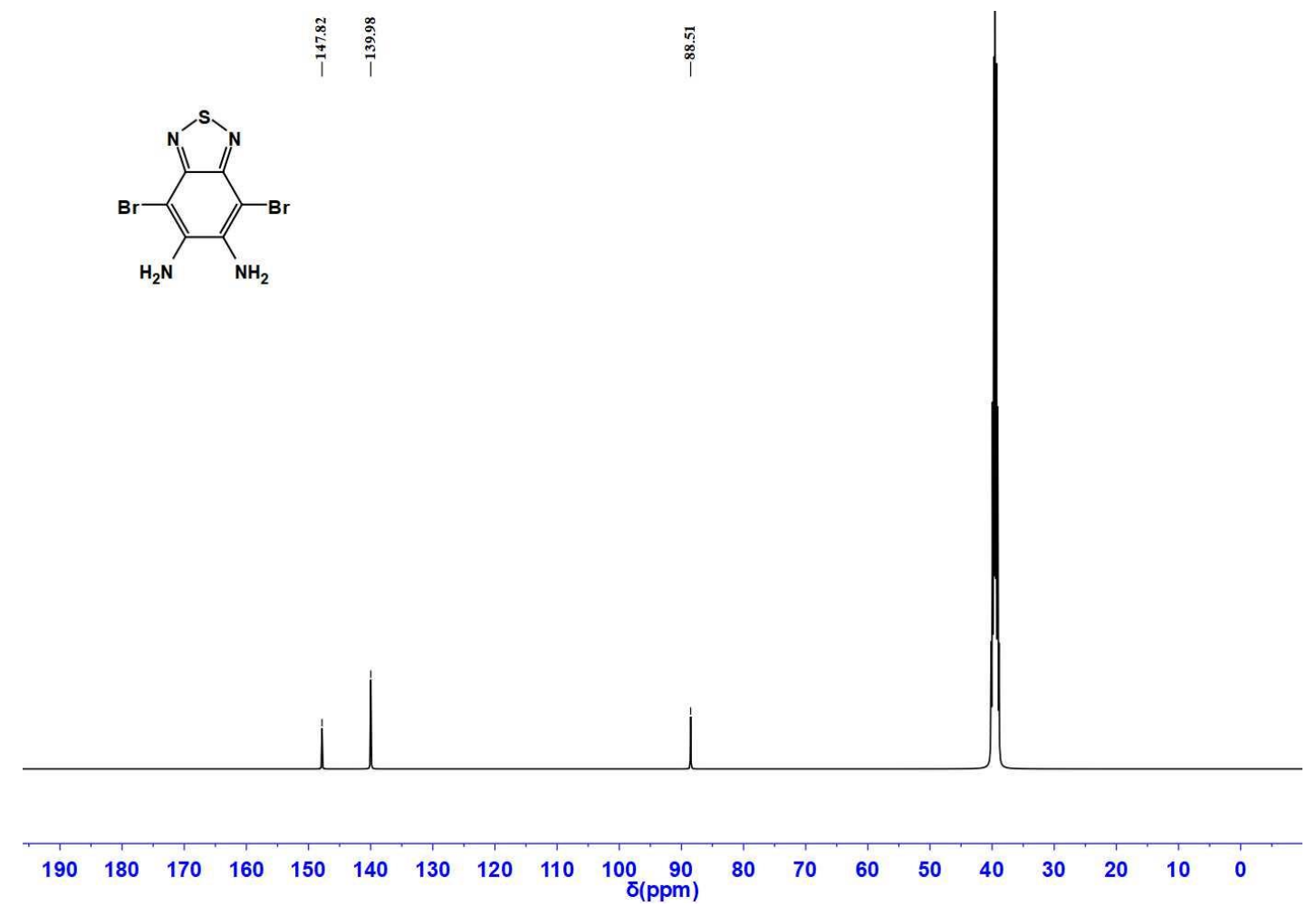

Figure S9. ${ }^{13} \mathrm{C}$ NMR spectrum of compound 4. (101 MHz, DMSO-d 6 ).

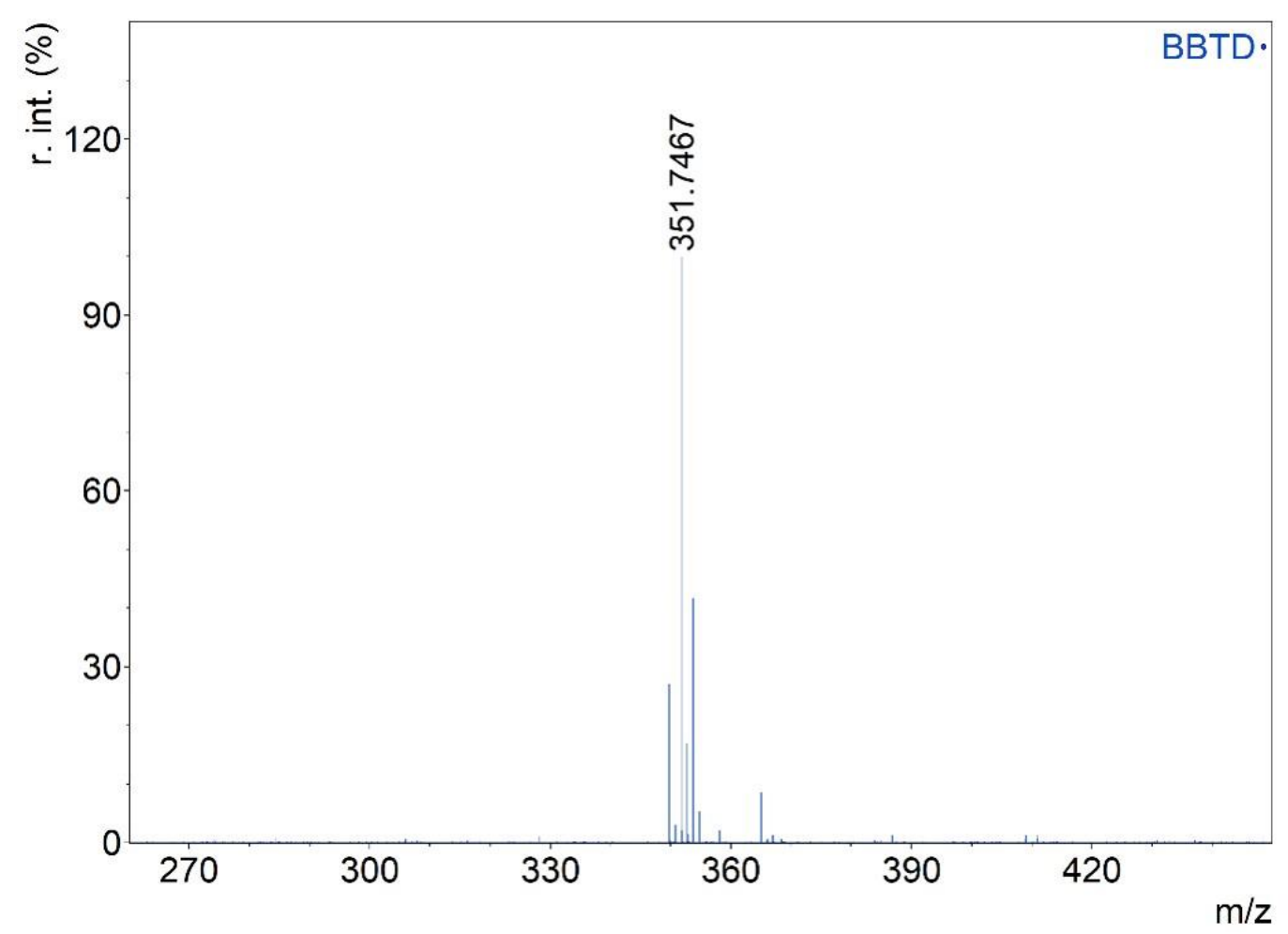

Figure S10. MALDI-TOF mass spectrum of BBTD. 

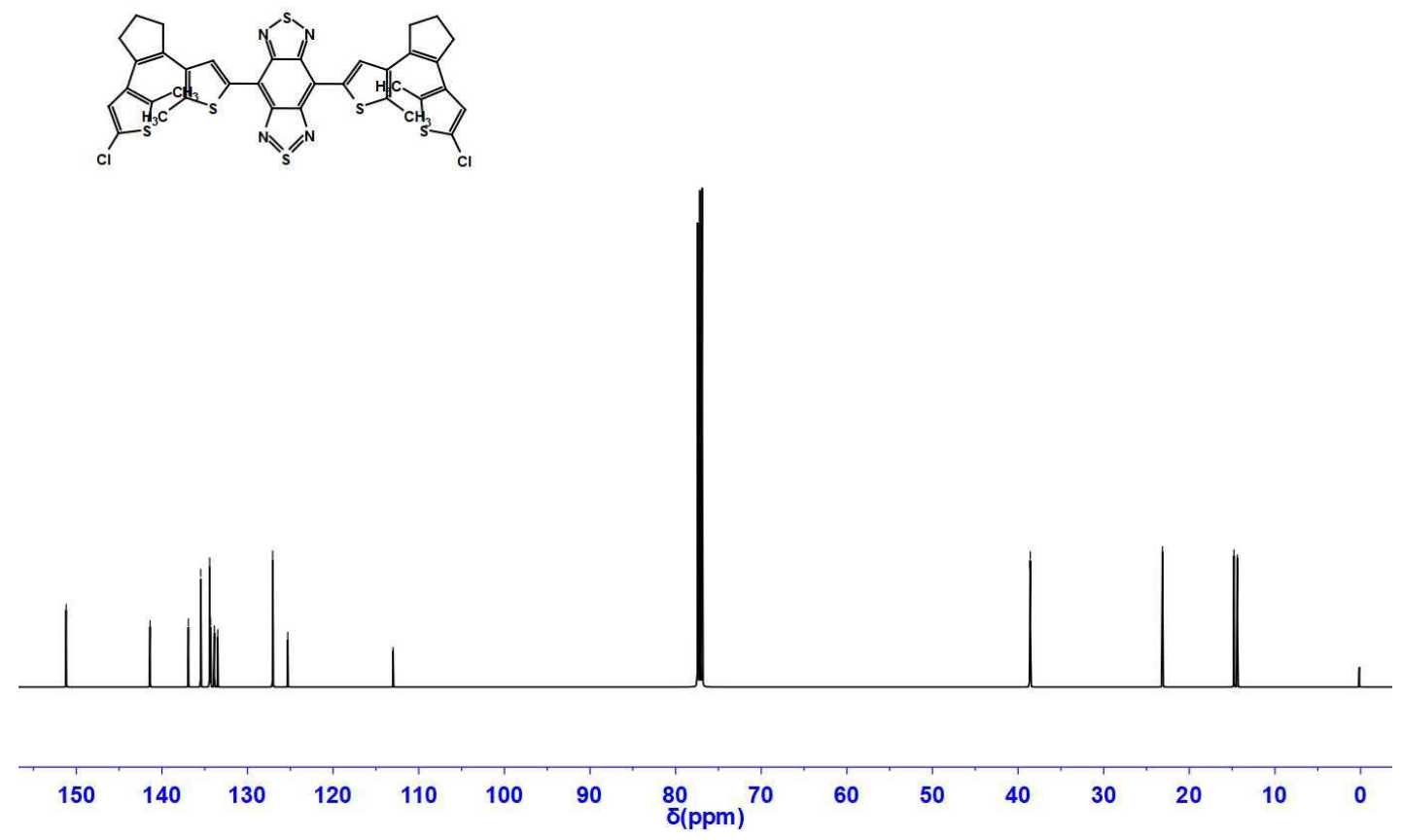

Figure S11. ${ }^{13} \mathrm{C}$ NMR spectrum of BBTD-BTE. (126 MHz, $\mathrm{CDCl}_{3}$ )

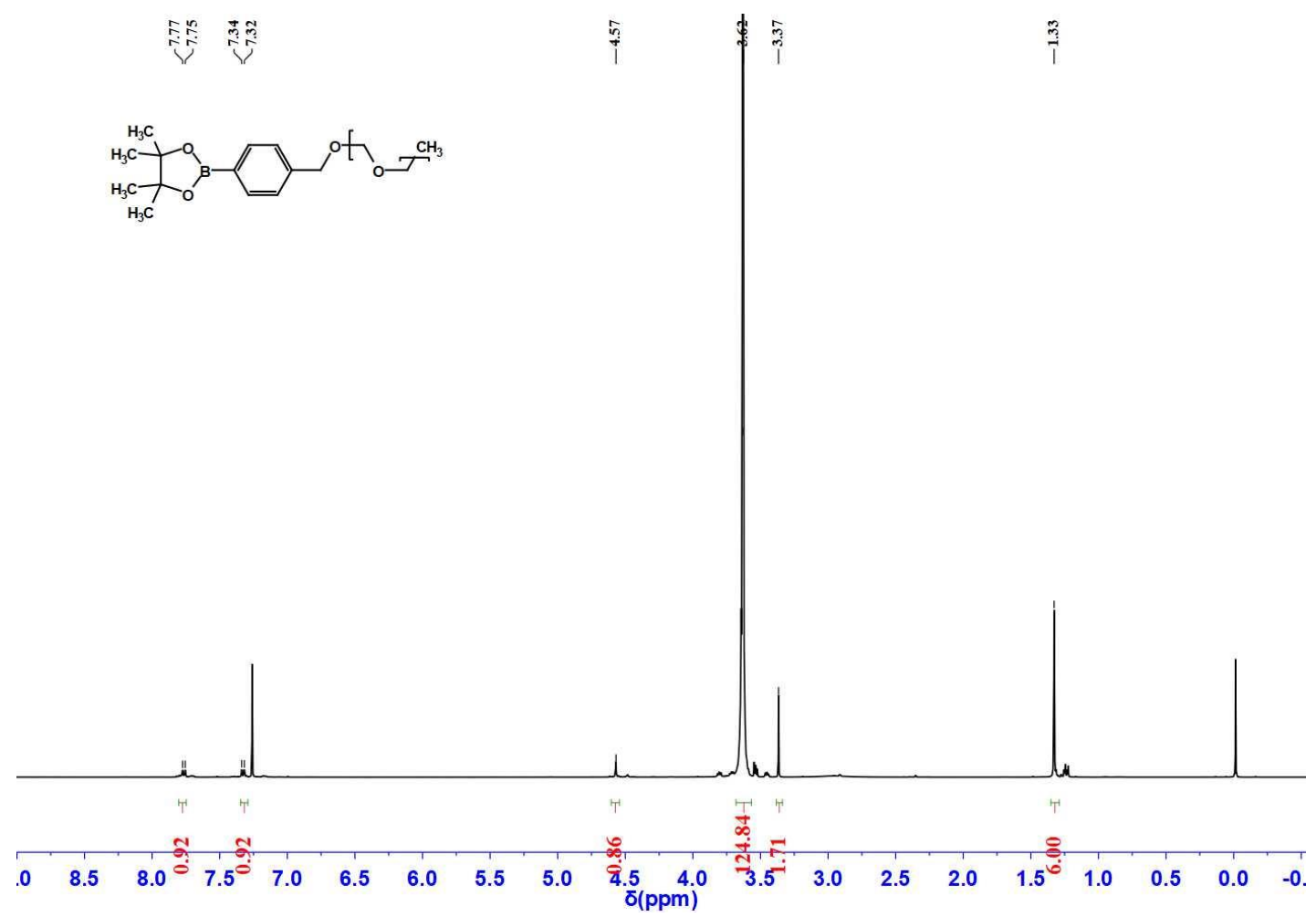

Figure S12. ${ }^{1} \mathrm{H}$ NMR spectrum of mPEG-Bpin. (400 $\left.\mathrm{MHz}, \mathrm{CDCl}_{3}\right)$ 


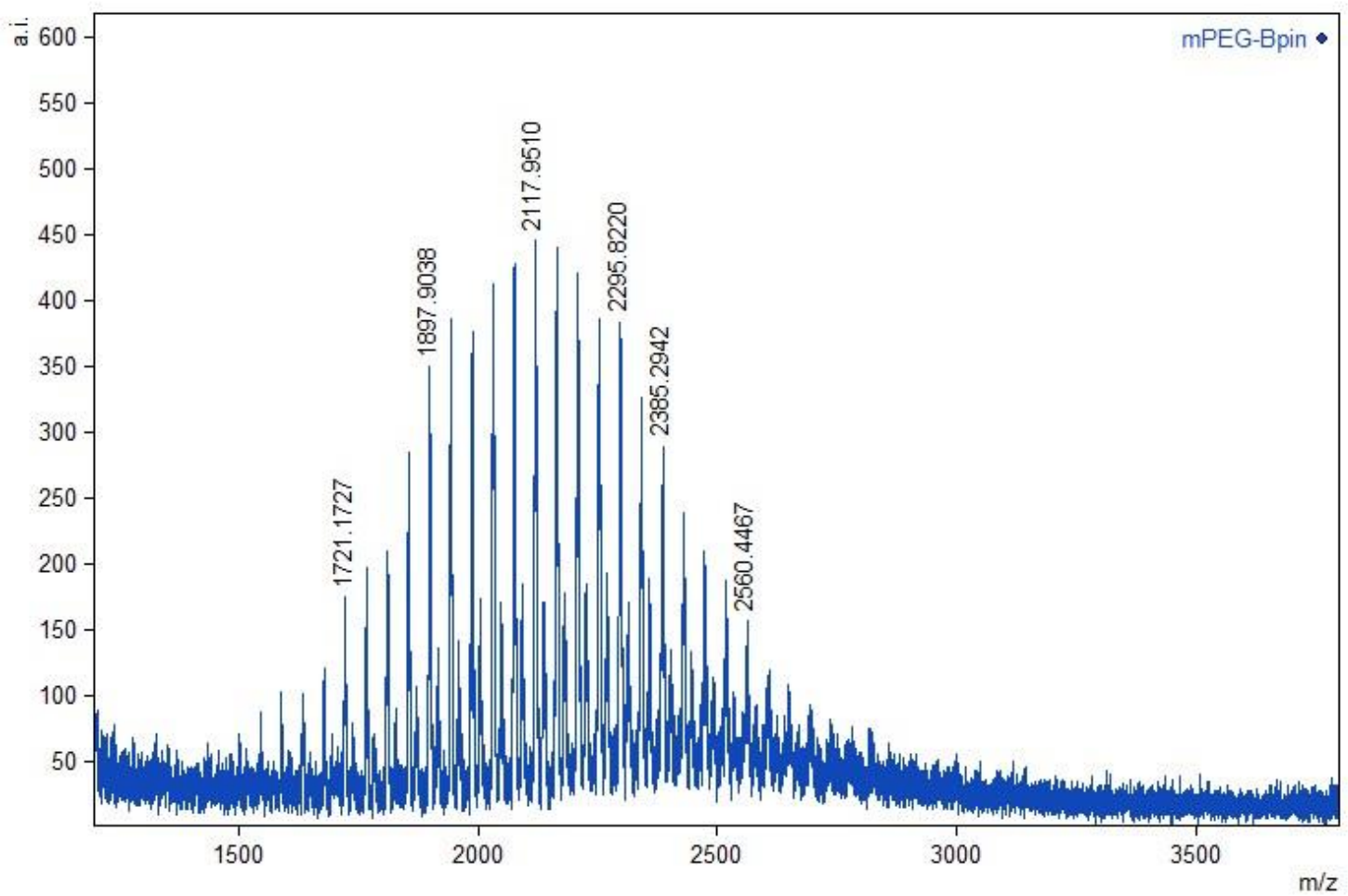

Figure S13. MALDI-TOF mass spectrum of mPEG-Bpin.

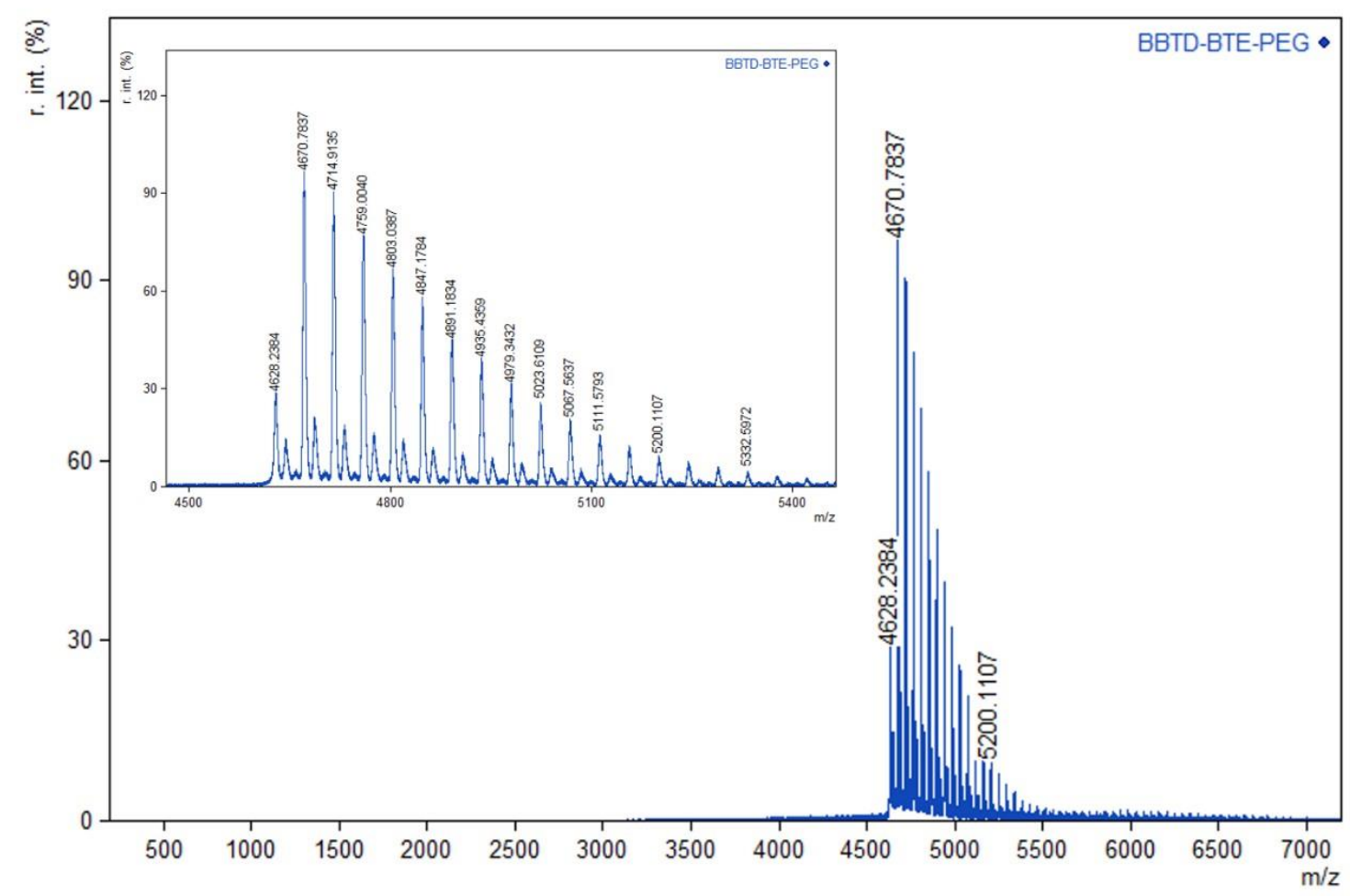

Figure S14. MALDI-TOF mass spectrum of BBTD-BTE-PEG. 


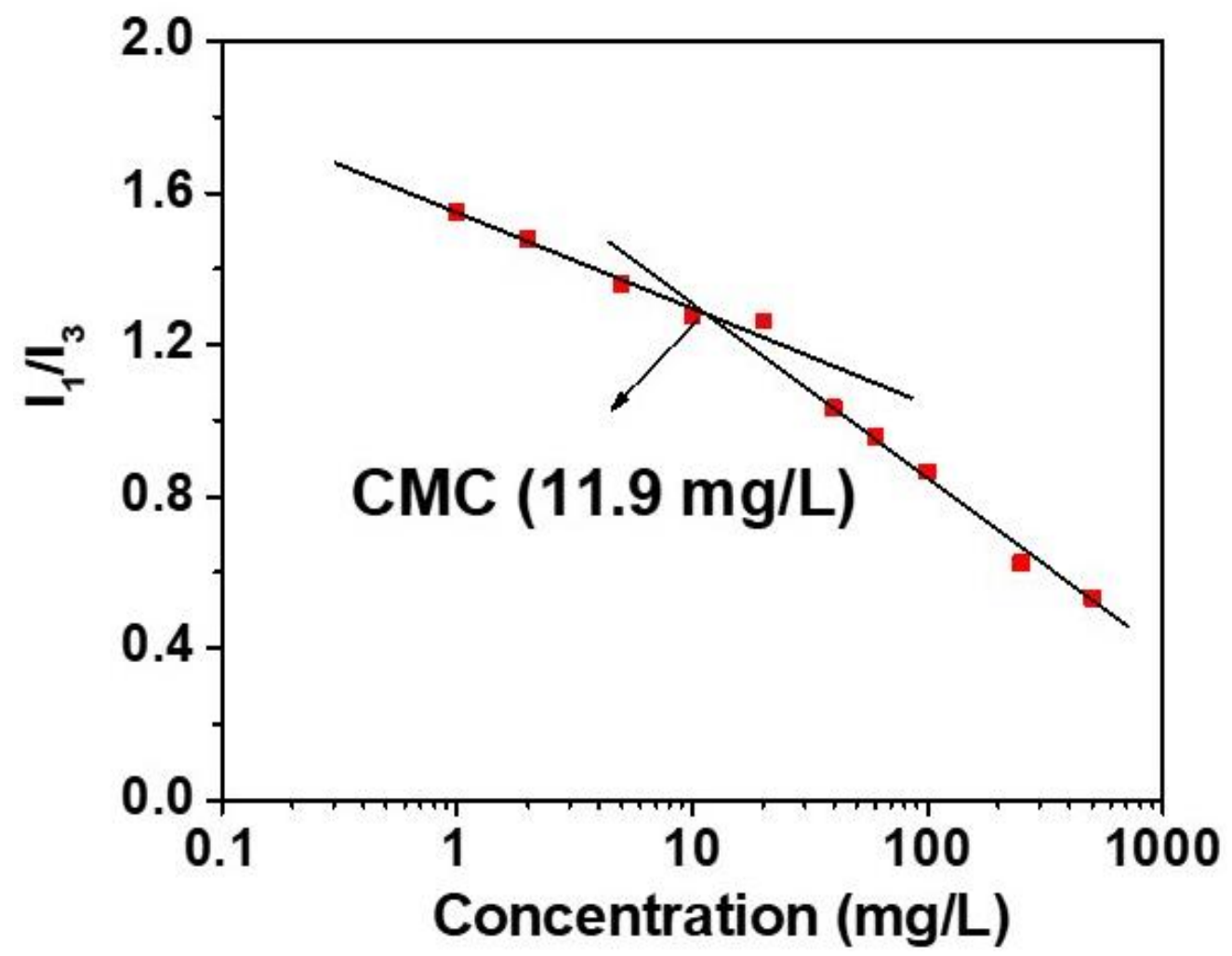

Figure S15. CMC measurement of BBTD-BTE-PEG. $\mathrm{I}_{1} / \mathrm{I}_{3}$ is the ratio of the fluorescence intensity at $373 \mathrm{~nm}\left(\mathrm{I}_{1}\right)$ to that at $391 \mathrm{~nm}\left(\mathrm{I}_{3}\right)$.

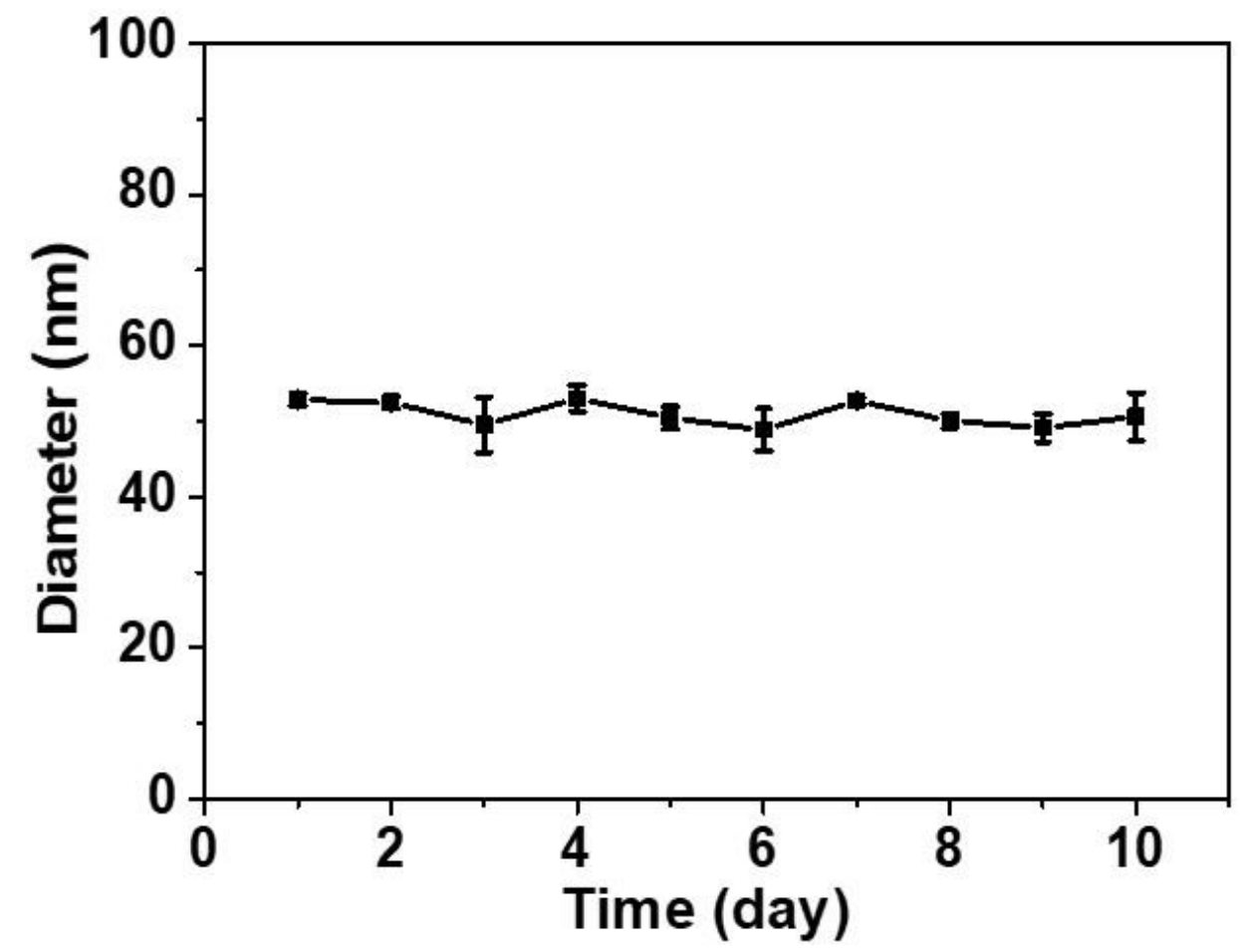

Figure S16. Evolution of the hydrodynamic size of BBTD-BTE-PEG over 10 days monitored by DLS. 


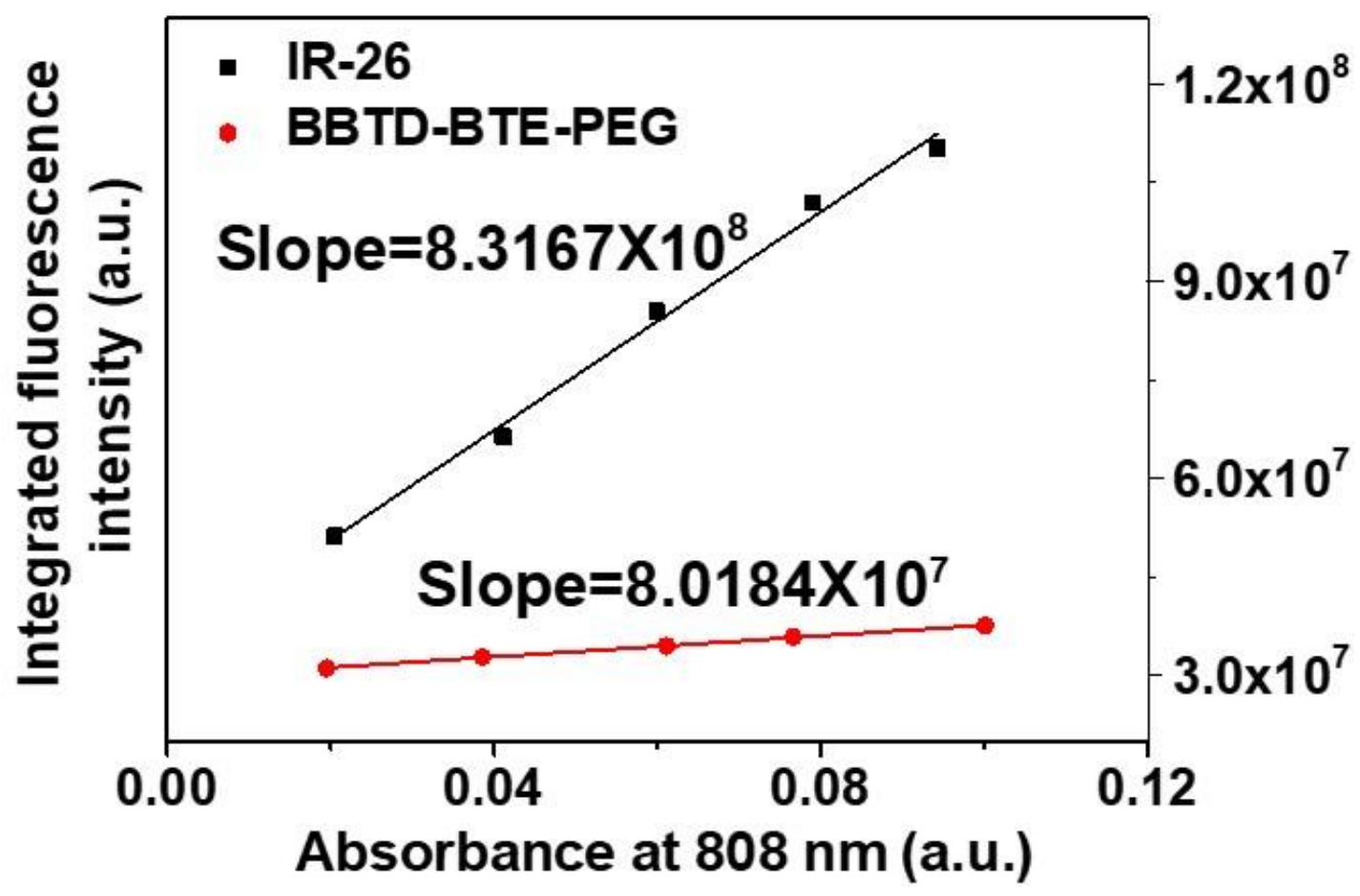

Figure S17. Plots of the integrated fluorescence intensities of IR 26 in DCE, BBTDBTE-PEG in water in the range of $850-1500 \mathrm{~nm}$ against the absorbance at $808 \mathrm{~nm}$.

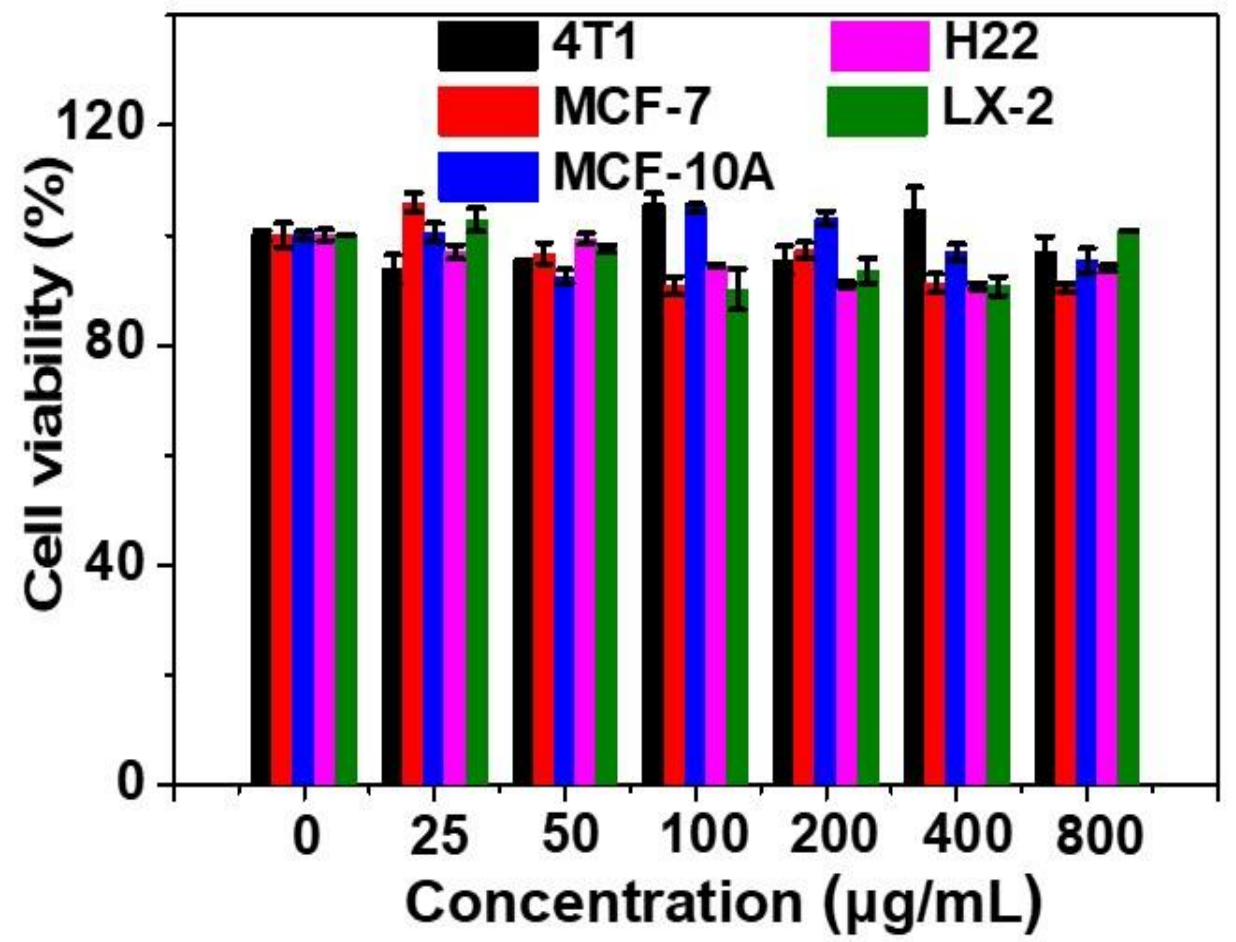

Figure S18. In vitro cytotoxicity of BBTD-BTE-PEG against 4T1, H22, MCF-7, MCF10A and LX-2 cells after $24 \mathrm{~h}$ incubation $(\mathrm{n}=4)$. 


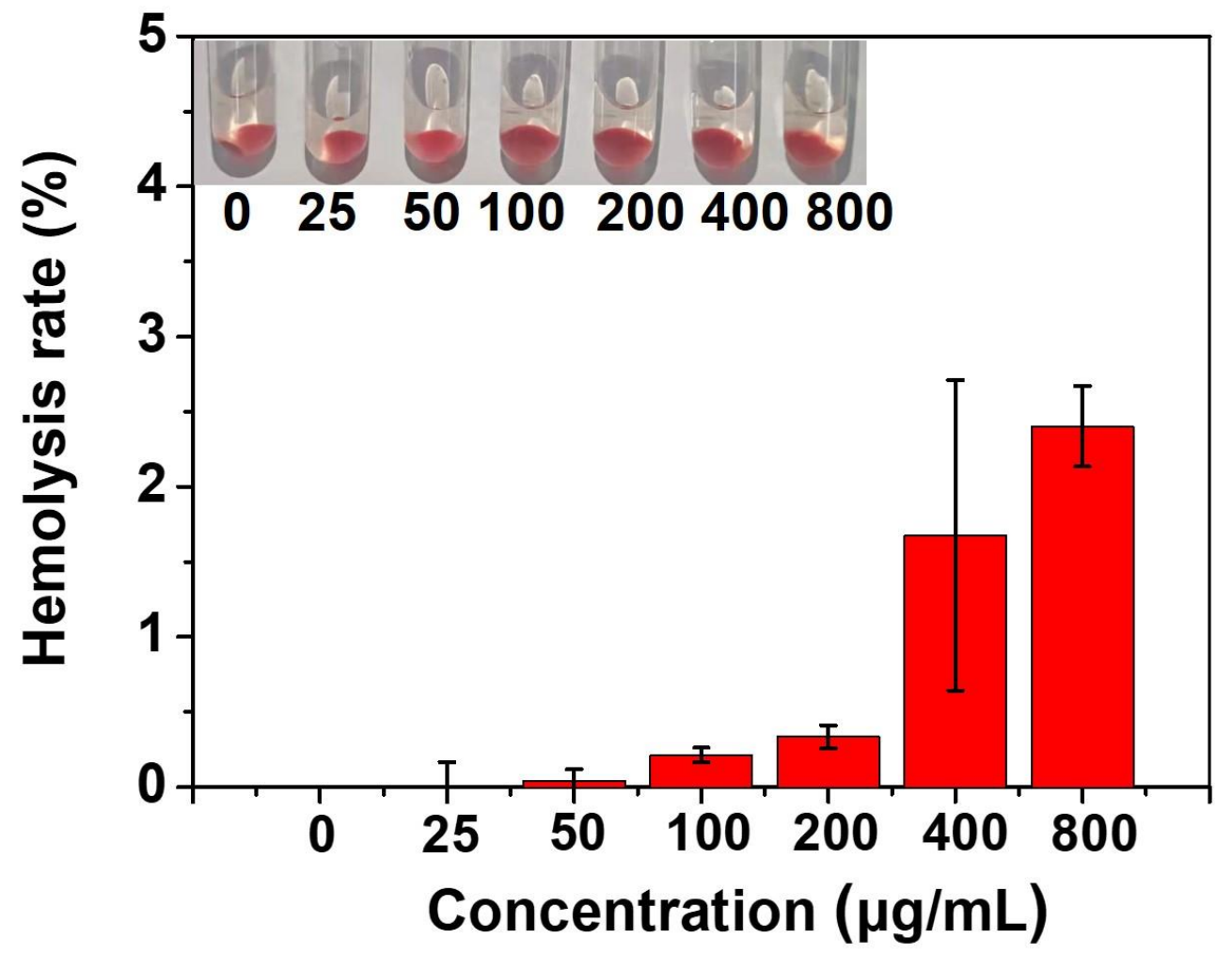

Figure S19. Hemolysis rate of BBTD-BTE-PEG at different concentrations.
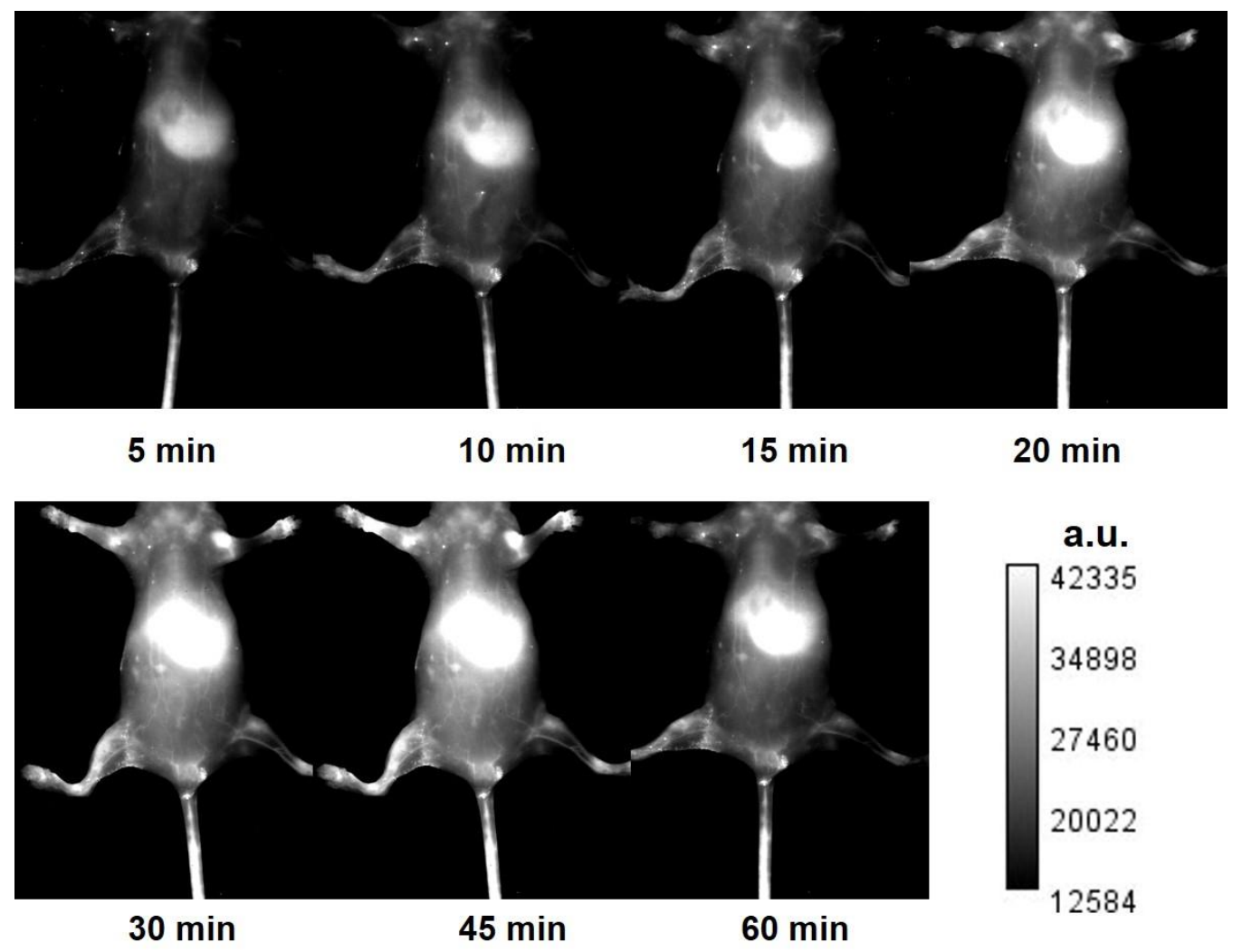

Figure S20. NIR-II fluorescence images of a H22 tumor-bearing mouse at different times after tail-vein injection of BBTD-BTE-PEG with $808 \mathrm{~nm}$ laser excitation and a $980 \mathrm{~nm}$ long-pass filter. 


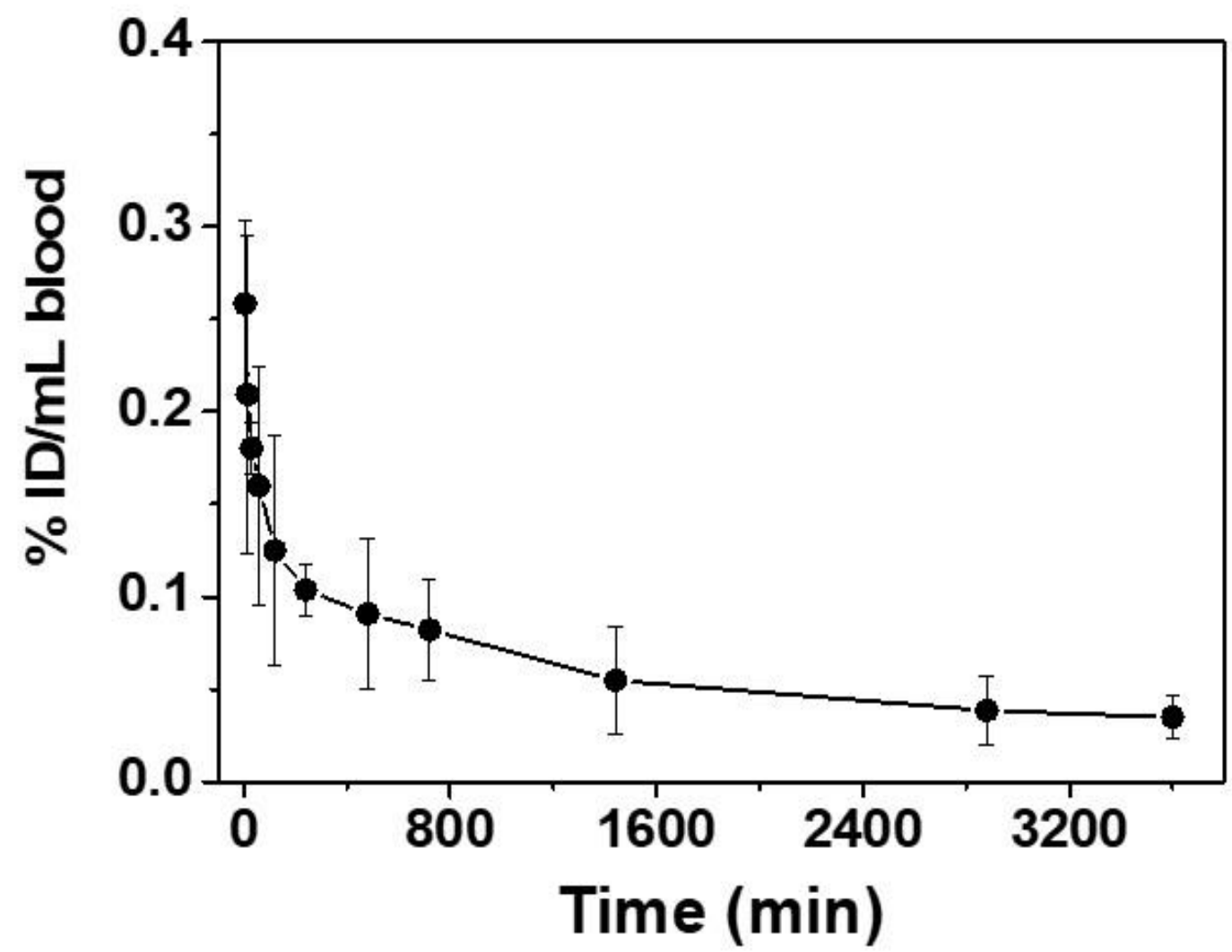

Figure S21. Evolution with time of the plasm concentration of BBTD-BTE-PEG after tail-vein injection.

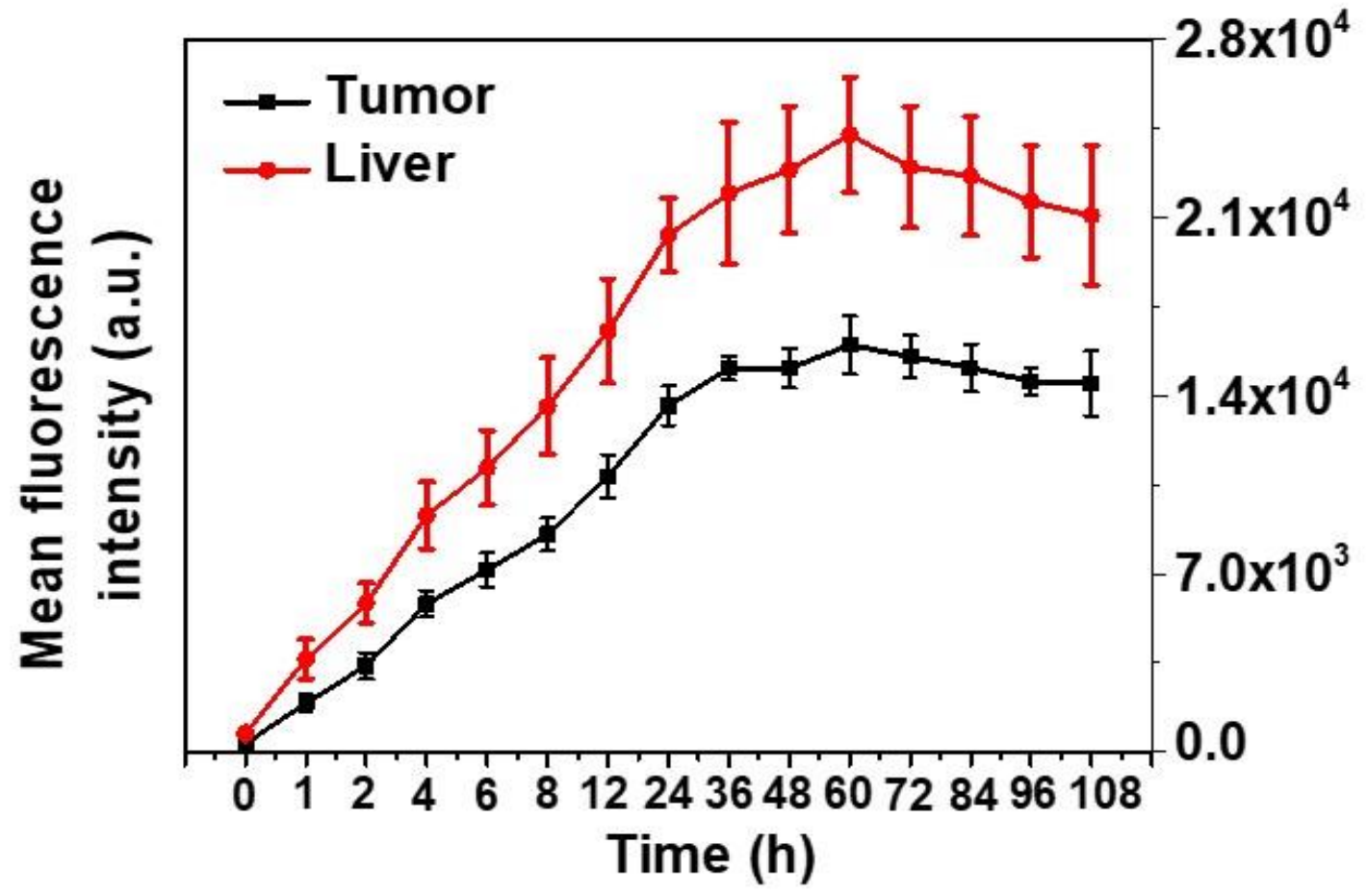

Figure S22. Evolution with time of the mean fluorescence intensities in the tumors and livers after tail-vein injection of BBTD-BTE-PEG. Data as mean values \pm S.D. $(n=3)$. 


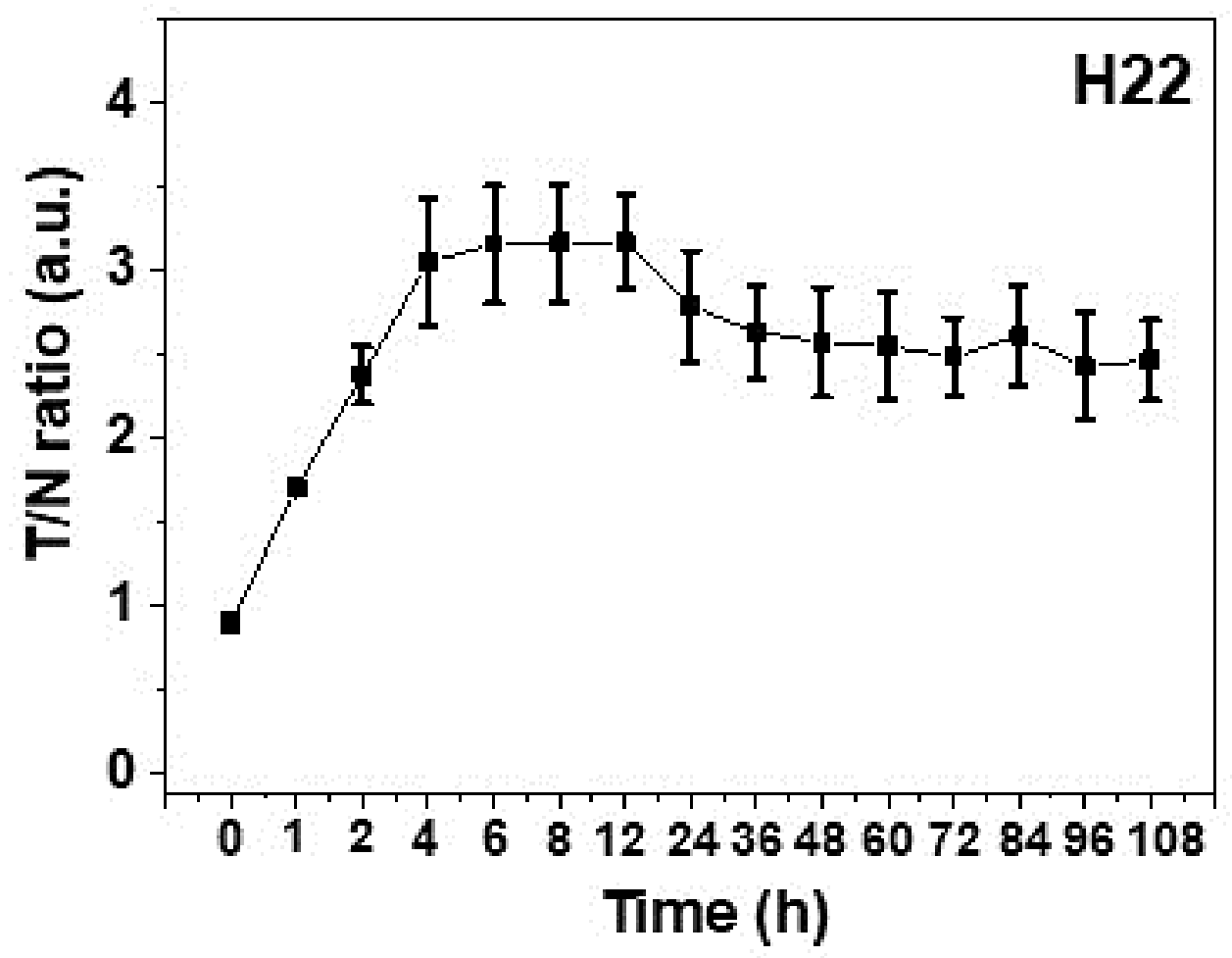

Figure S23. Evolution with time of the $\mathrm{T} / \mathrm{N}$ ratios of $\mathrm{H} 22$ tumor-bearing mice after tailvein injection of BBTD-BTE-PEG. Data as mean values \pm S.D. $(n=3)$.

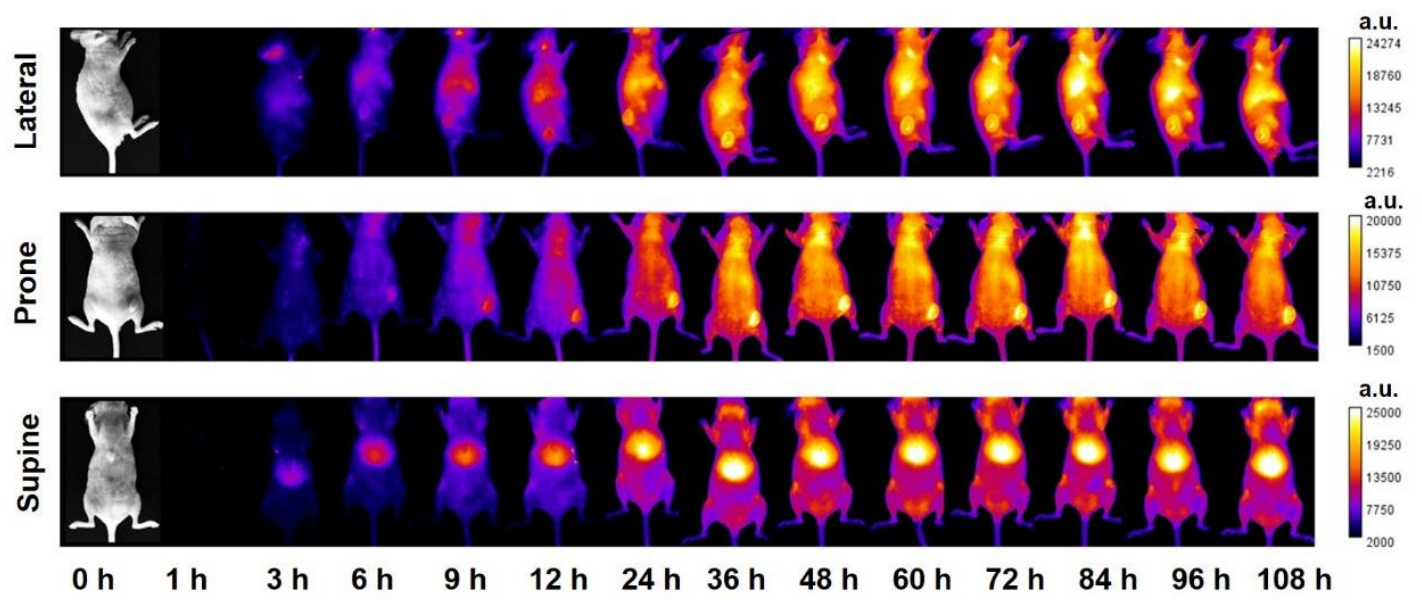

Figure S24. NIR-II fluorescence images of a 4T1 tumor-bearing mouse at different times after tail-vein injection of BBTD-BTE-PEG with $808 \mathrm{~nm}$ laser excitation and a $980 \mathrm{~nm}$ long-pass filter. 


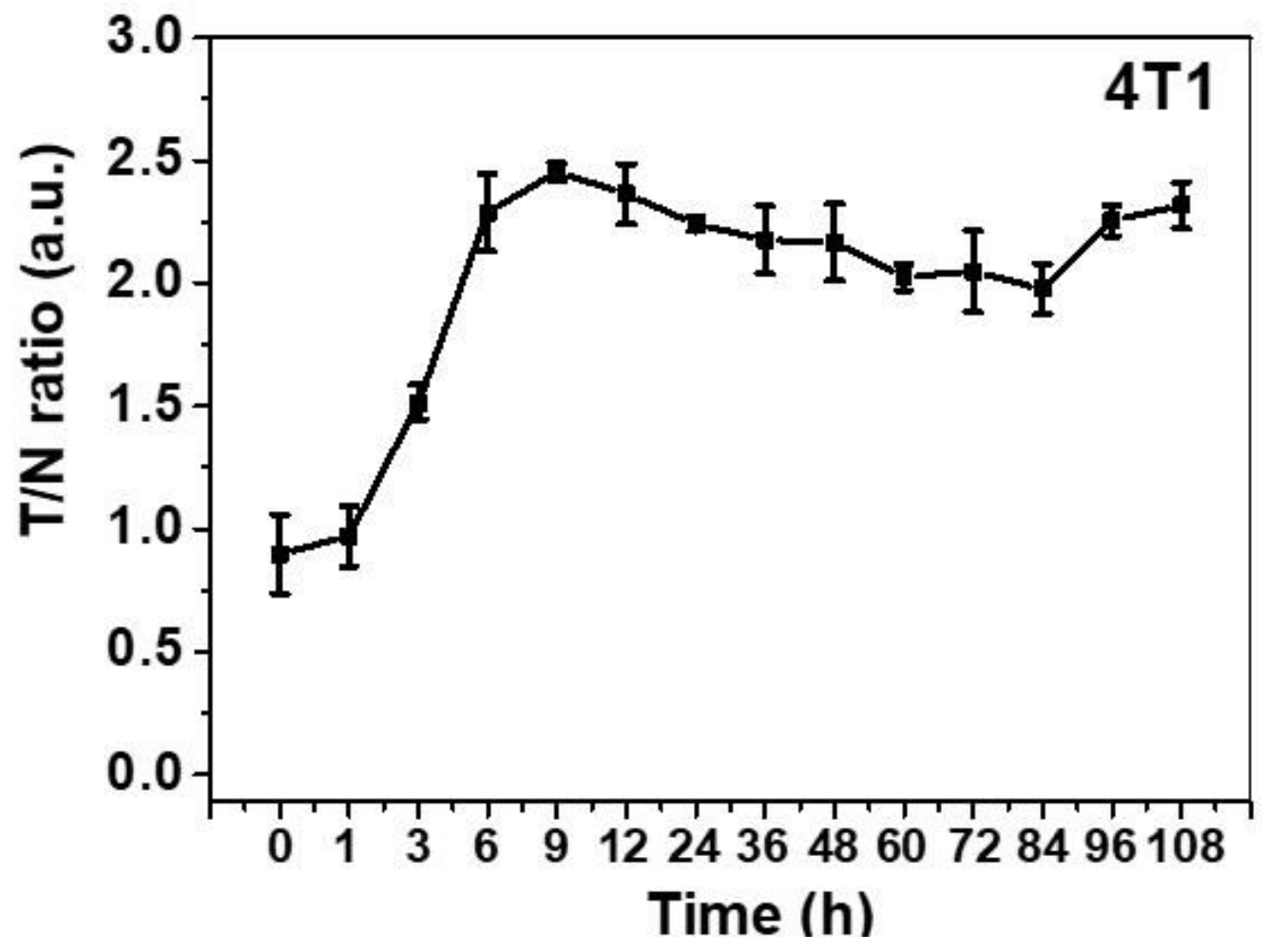

Figure S25. Evolution with time of the T/N ratios of $4 \mathrm{~T} 1$ tumor-bearing mice after tailvein injection of BBTD-BTE-PEG. Data as mean values \pm S.D. $(n=3)$.
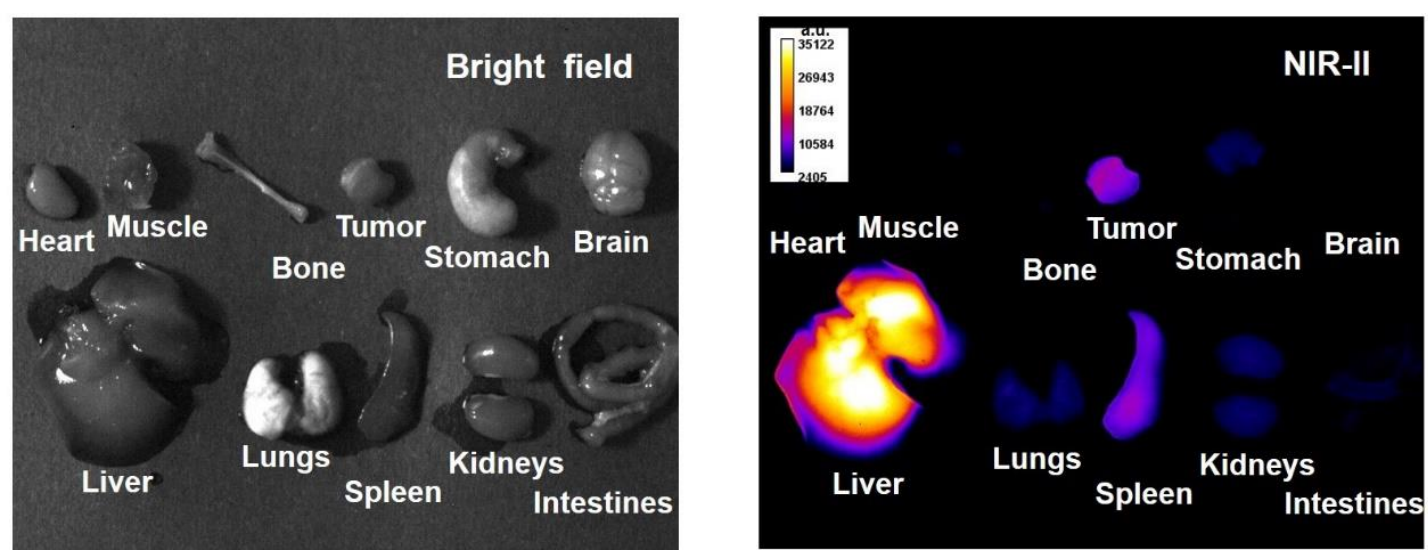

Figure S26. Bright field and NIR-II Images of the main organs, tissues and tumor excised from a $4 \mathrm{~T} 1$ tumor-bearing mouse sacrificed on the $5^{\text {th }}$ day after tail-vein injection of BBTD-BTE-PEG. 


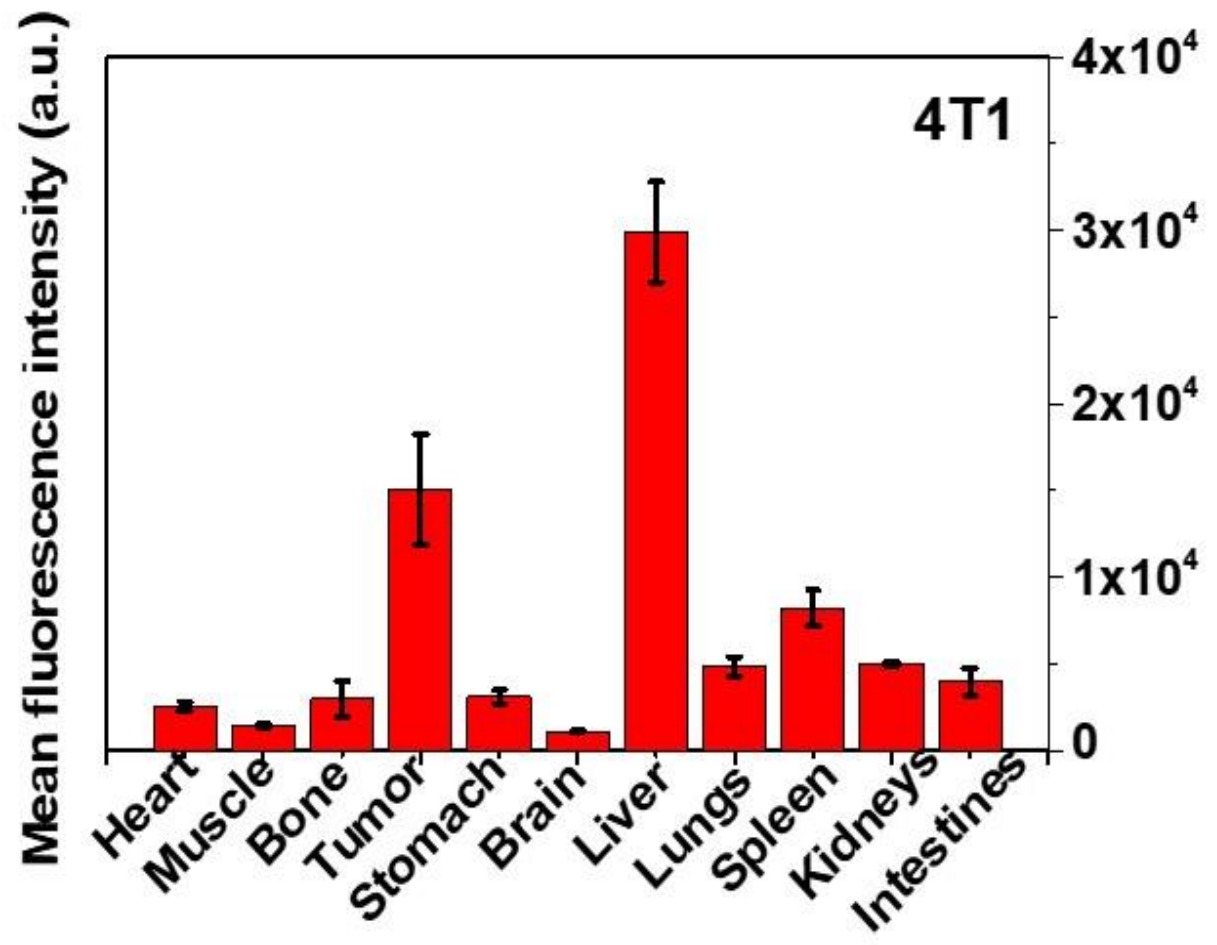

Figure S27. The histogram of the NIR-II signals of the organs, tissues and tumors. Data as mean values \pm S.D. $(n=3)$.

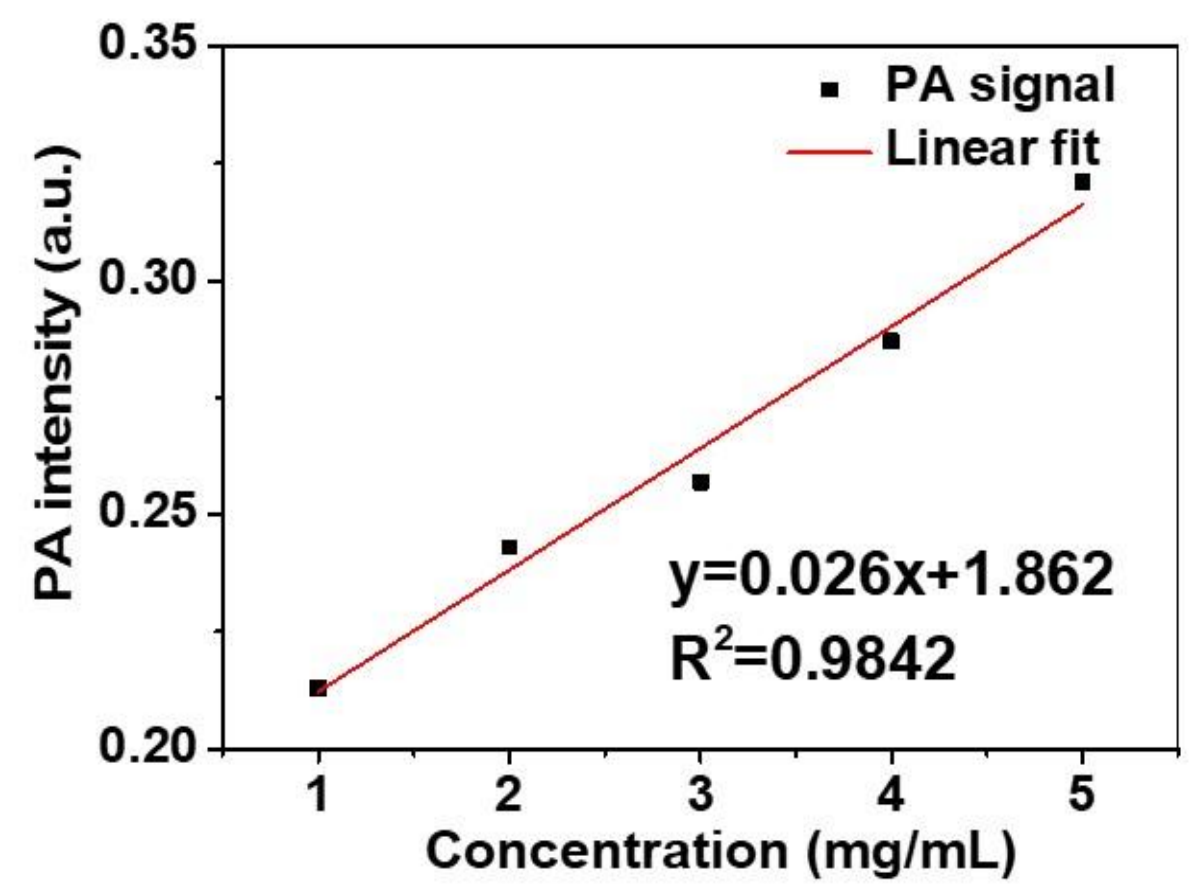

Figure S28. Plot of PA amplitude versus BBTD-BTE-PEG concentration showing a linear relationship between the two entities. 


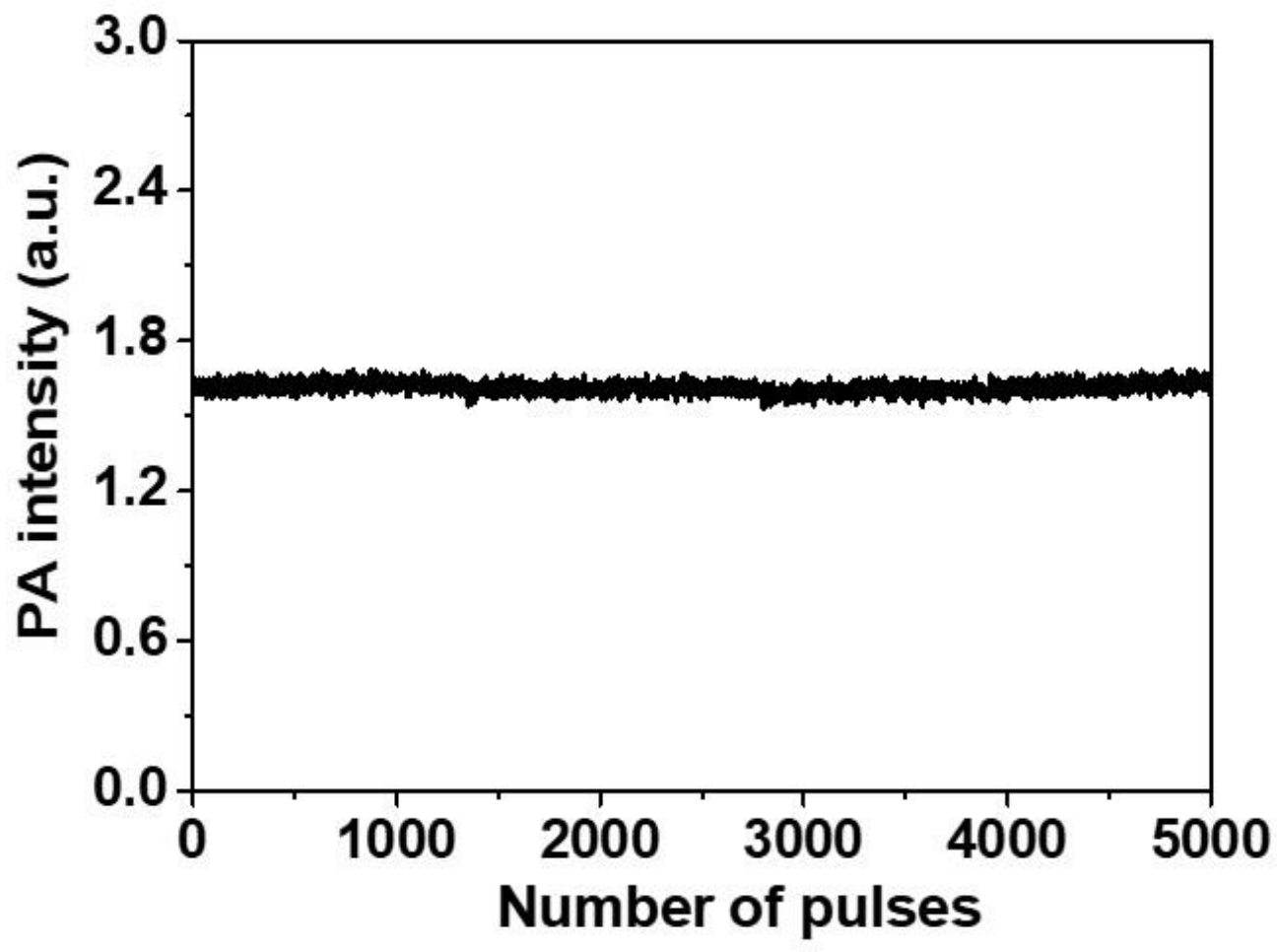

Figure S29. PA signal intensity variation of BBTD-BTE-PEG upon irradiation with $808 \mathrm{~nm}$ laser for 5000 times.

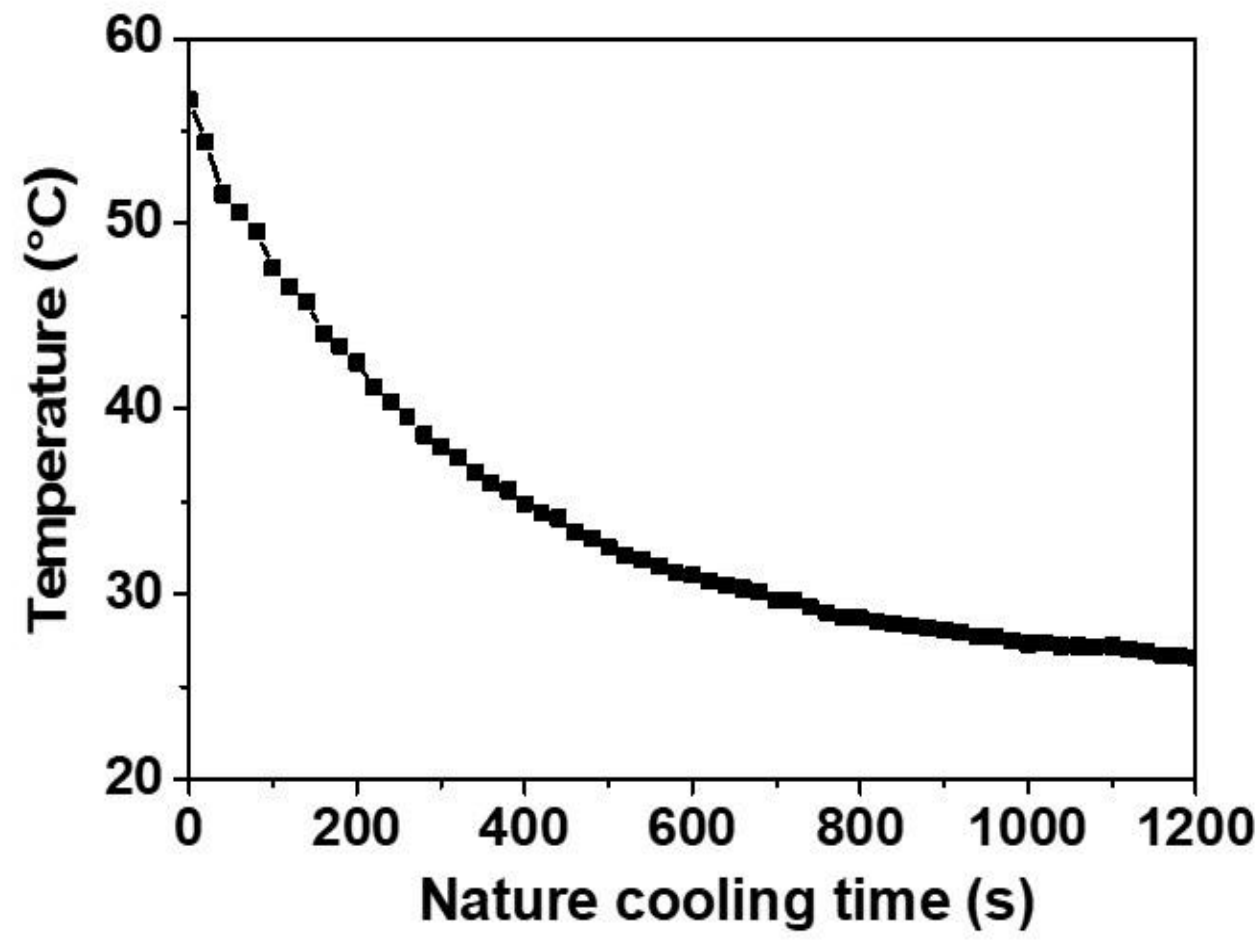

Figure S30. Naturally cooling curve of BBTD-BTE-PEG after irradiated to the plateau with an $808 \mathrm{~nm}$ laser $\left(1.0 \mathrm{~W} / \mathrm{cm}^{2}\right)$. 


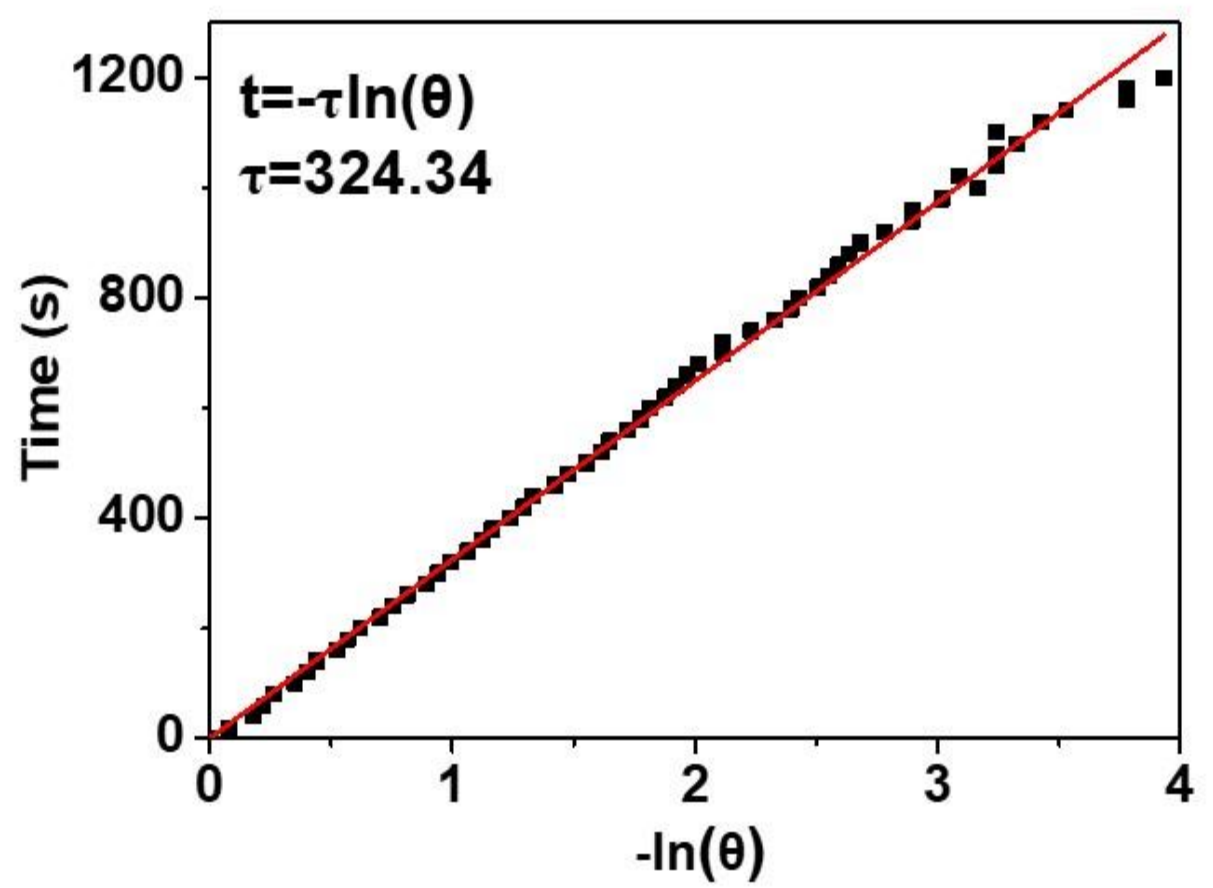

Figure S31. The relationship between the cooling time and the negative natural logarithm of the temperature driving force obtained from the cooling phase shown in Figure S26.

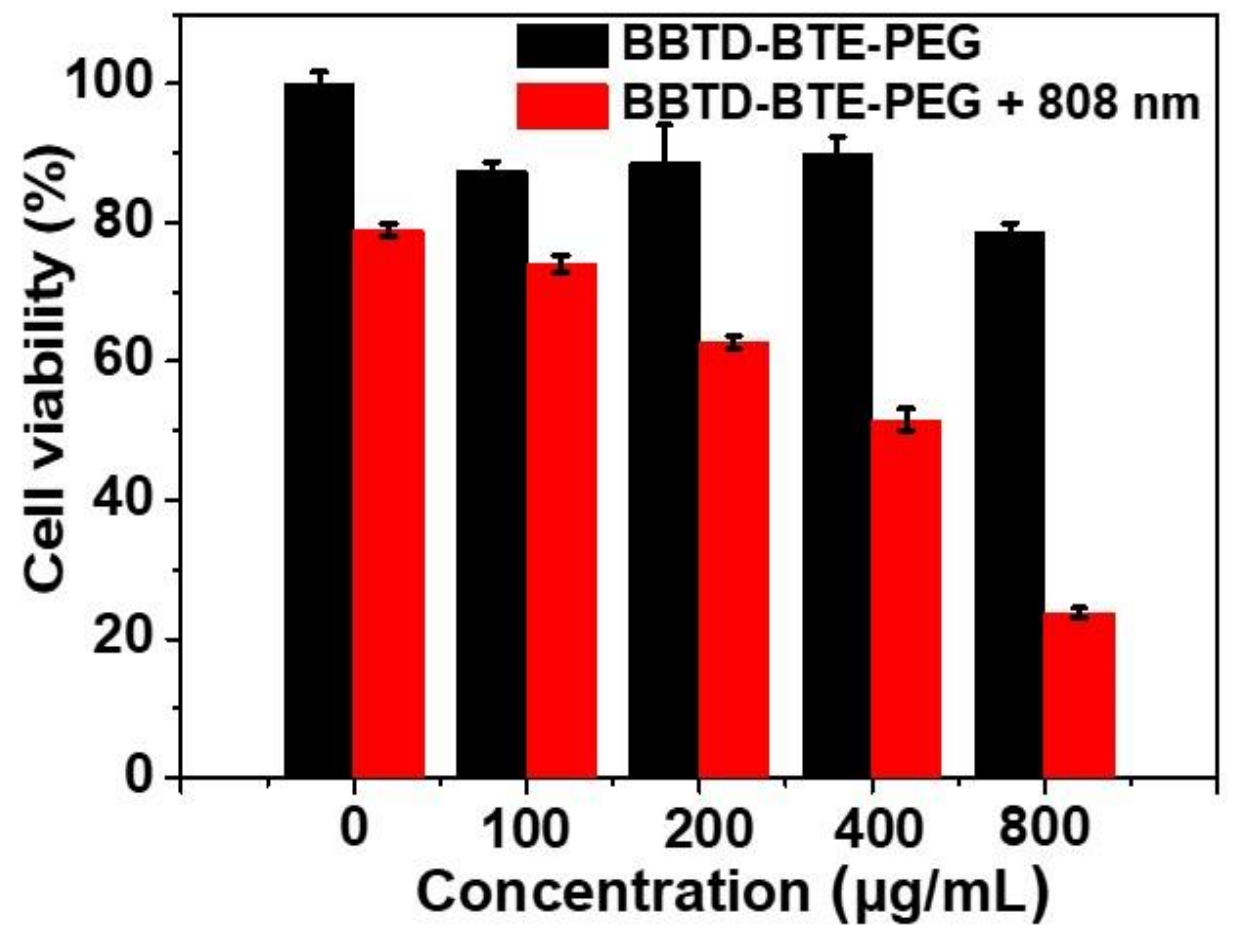

Figure S32. In vitro cytotoxicity of BBTD-BTE-PEG against $\mathrm{H} 22$ cells with and without $808 \mathrm{~nm}$ laser irradiation at a power density of $0.3 \mathrm{~W} / \mathrm{cm}^{2}$ for $5 \mathrm{~min}(\mathrm{n}=4)$. 


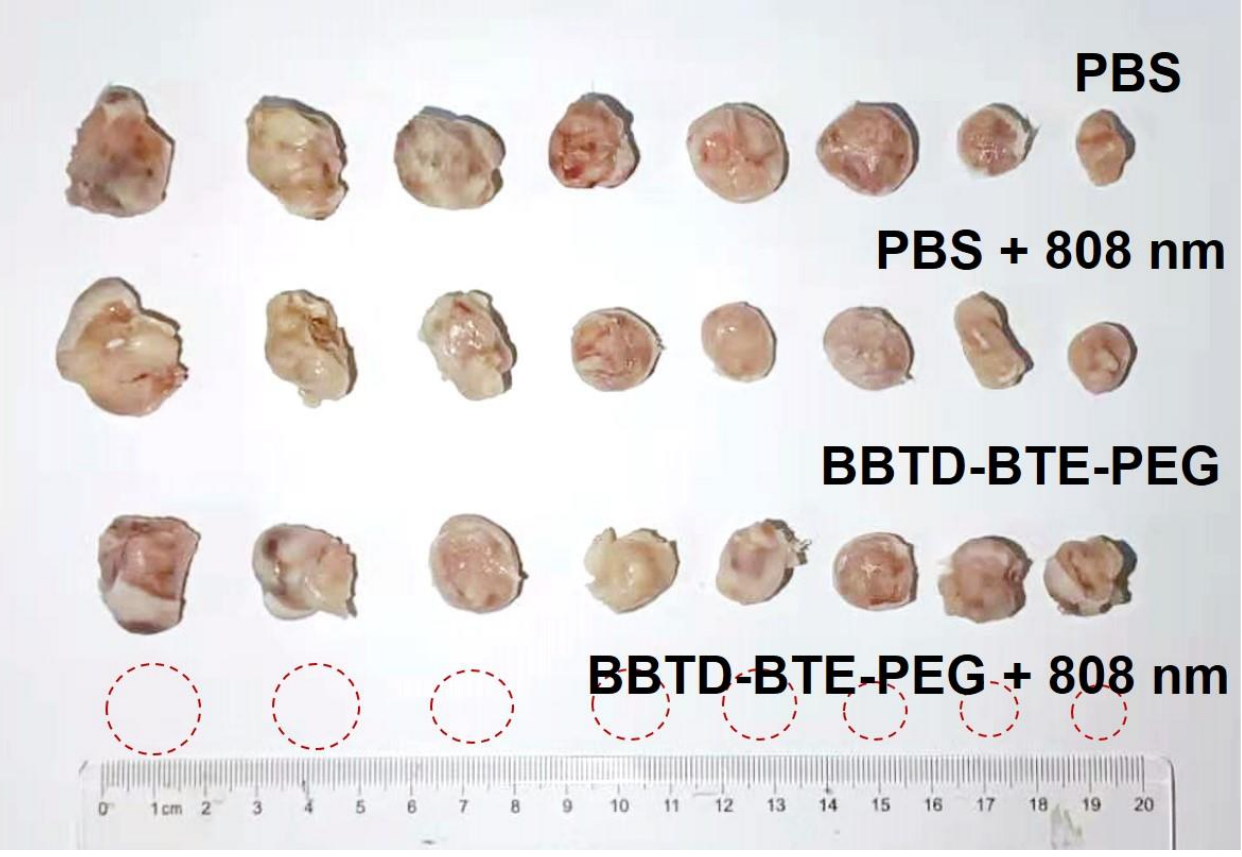

Figure S33. Photographs of the H22 tumors excised from the mice after the treatments with PBS, PBS + laser, BBTD-BTE-PEG, BBTD-BTE-PEG + laser as indicated.

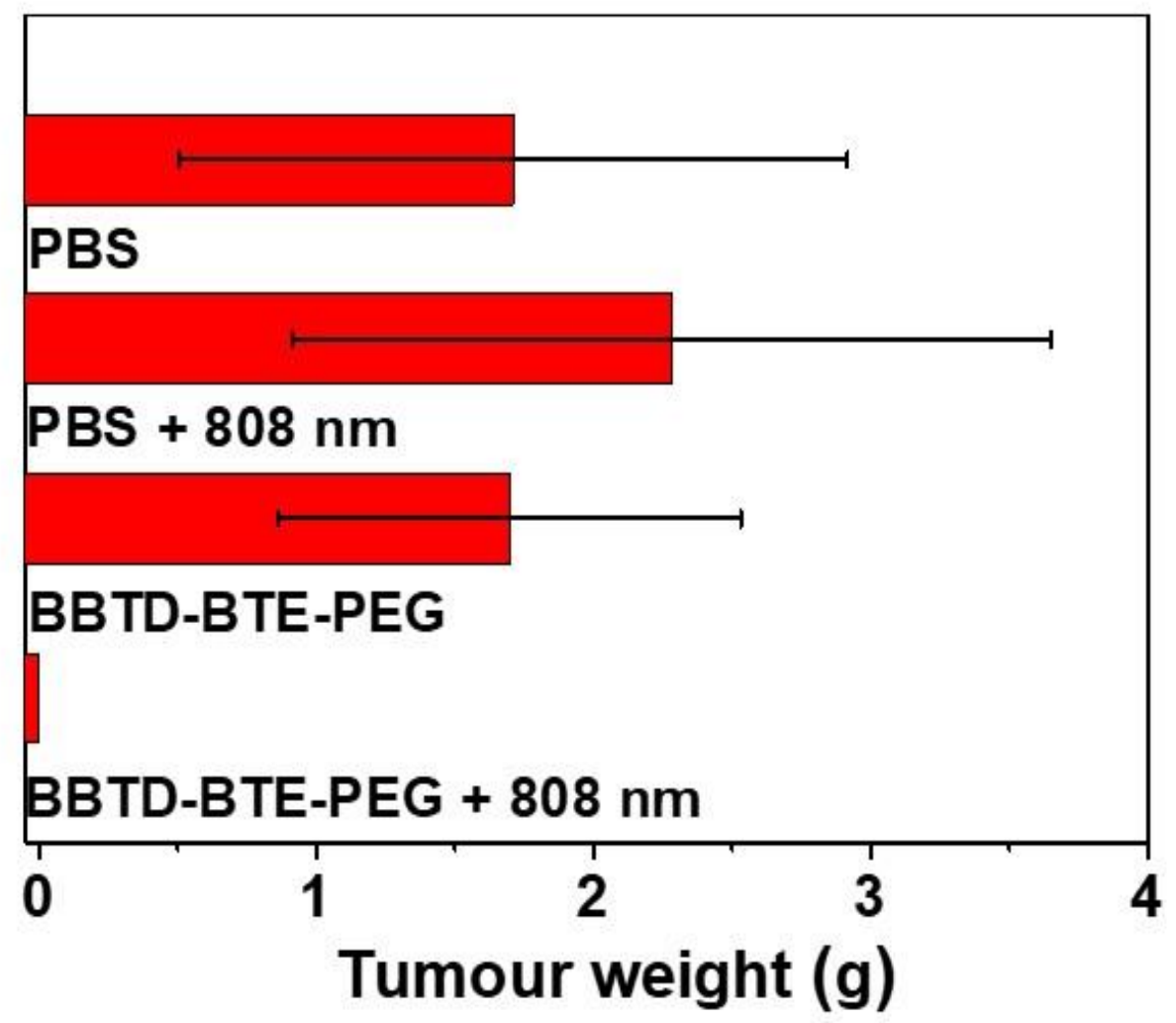

Figure S34. The weights of the tumors excised from the mice after the treatments with PBS, PBS + laser, BBTD-BTE-PEG, BBTD-BTE-PEG + laser as indicated. 
Table S1. Blood routine tests of the mice on the $14^{\text {th }}$ day after tail-vein injection of BBTD-BTE-PEG. PBS-treated healthy mice were used as control. Data as mean values \pm S.D. $(n=3)$.

\begin{tabular}{cccc}
\hline & Unit & Control & BBTD-BTE-PEG \\
\hline WBC & $\times 10^{9} \mathrm{cell} / \mathrm{L}$ & $4.5 \pm 0.67$ & $3.78 \pm 0.59$ \\
RBC & $\times 10^{12} \mathrm{cell} / \mathrm{L}$ & $8.7 \pm 0.19$ & $8.39 \pm 0.16$ \\
HGB & $\mathrm{g} / \mathrm{L}$ & $146.0 \pm 2.16$ & $136.33 \pm 2.87$ \\
HCT & $\%$ & $46.6 \pm 1.46$ & $45.37 \pm 0.97$ \\
MCV & $\mathrm{fL}$ & $53.8 \pm 1.10$ & $54.10 \pm 1.39$ \\
MCH & $\mathrm{pg}$ & $16.8 \pm 0.25$ & $16.27 \pm 0.29$ \\
MCHC & $\mathrm{g} / \mathrm{L}$ & $313.0 \pm 5.66$ & $300.67 \pm 3.40$ \\
RDW & $\%$ & $14.0 \pm 0.37$ & $15.37 \pm 0.76$ \\
PLT & $\times 10^{9} \mathrm{cell} / \mathrm{L}$ & $1111.3 \pm 116.66$ & $1068.00 \pm 45.89$ \\
\hline
\end{tabular}
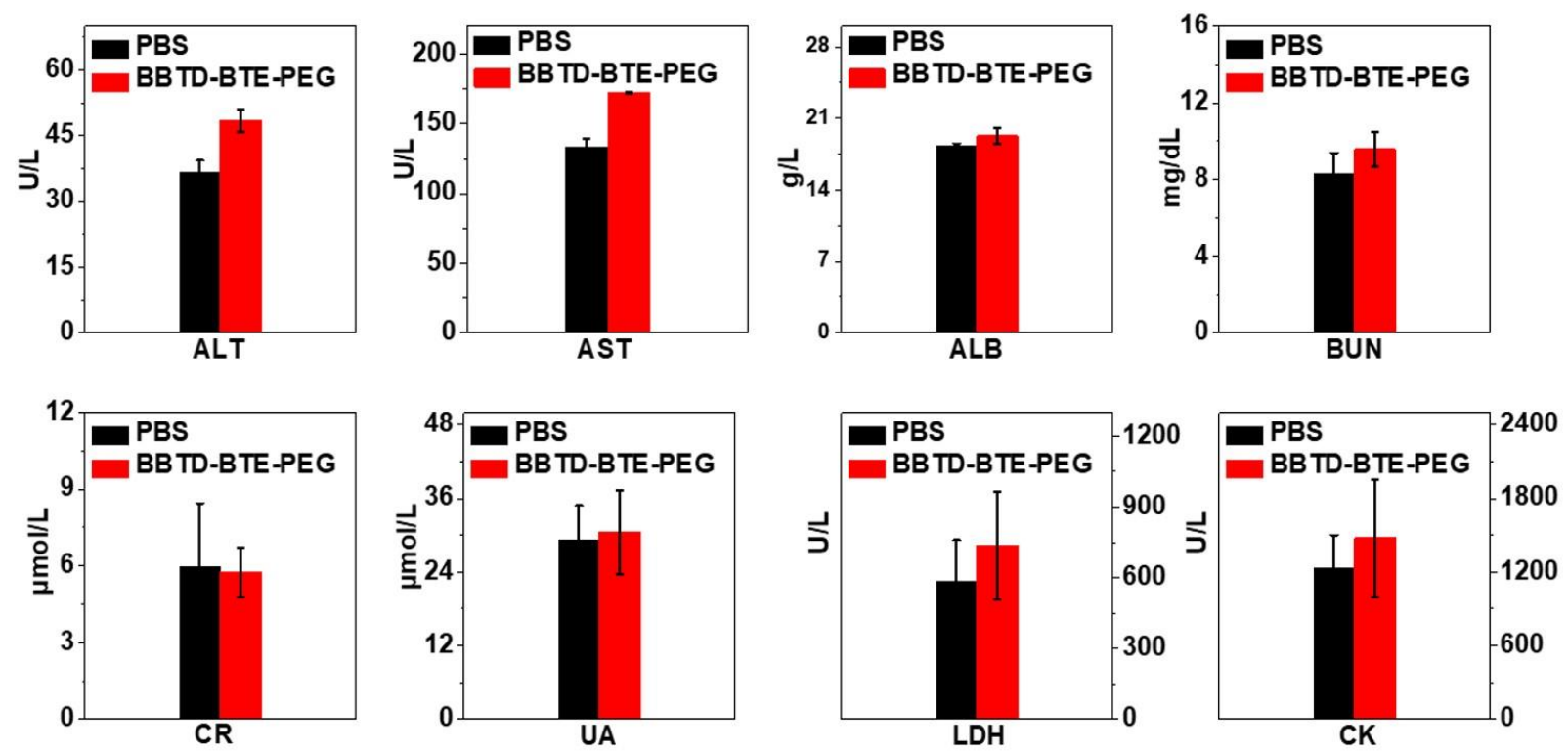

Figure S35. Blood biochemistry analysis of the mice on the $14^{\text {th }}$ day after tail-vein injection of BBTD-BTE-PEG. PBS-treated healthy mice were used as control. Data as mean values \pm S.D. $(n=3)$. 


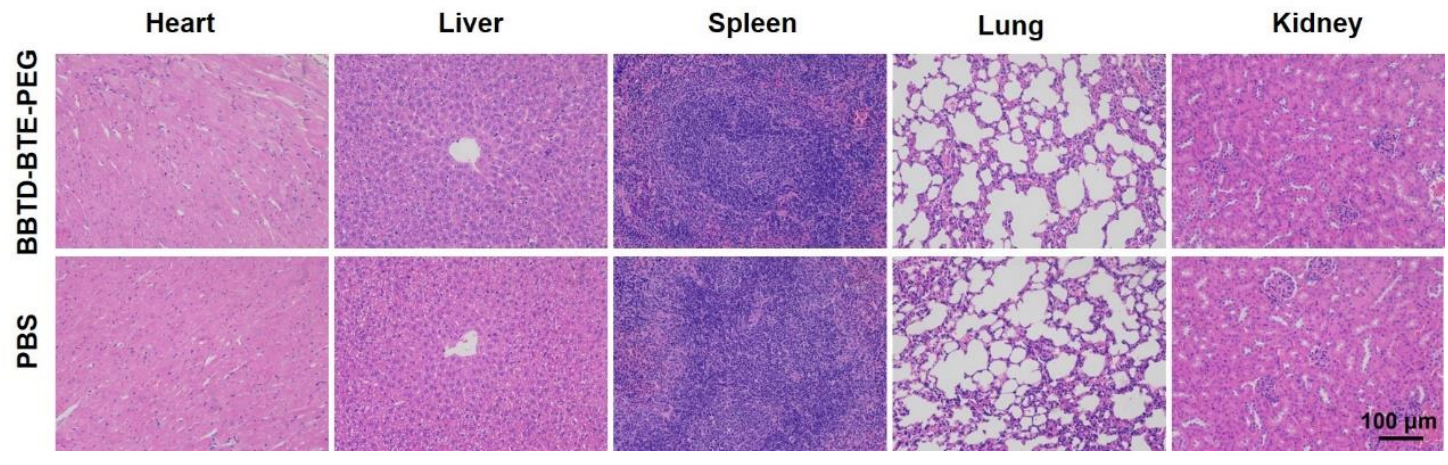

Figure S36. Images of the H\&E-stained organ slices from the mice on the $14^{\text {th }}$ day after tail-vein injection of BBTD-BTE-PEG. PBS-treated healthy mice were used as control. 


\section{Reference}

1. Sheng, Z.; Li, Y.; Hu, D.; Min, T.; Gao, D.; Ni, J.-S.; Zhang, P.; Wang, Y.; Liu, X.; Li, K.; Zheng, H.; Tang, B. Z. Centimeter-Deep NIR-II Fluorescence Imaging with Nontoxic AIE Probes in Nonhuman Primates. Research 2020, $2020,4074593$.

2 Frisch, M. J.; Trucks, G. W.; Schlegel, H. B.; Scuseria, G. E.; Robb, M. A.; Cheeseman, J. R.; Scalmani, G.; Barone, V .; Petersson, G. A.; Nakatsuji, H.; Li, X.; Caricato, M.; Marenich, A. V.; Bloino, J.; Janesko, B. G.; Gomperts, R.; Mennucci, B.; Hratchian, H. P.; Ortiz, J. V.; Izmaylov, A. F.; Sonnenberg, J. L.; Williams-Young, D.; Ding, F.; Lipparini, F.; Egidi, F.; Goings, J.; Peng, B.; Petrone, A.; Henderson, T.; Ranasinghe, D.; Zakrzewski, V. G.; Gao, J.; Rega, N.; Zheng, G.; Liang, W.; Hada, M.; Ehara, M.; Toyota, K.; Fukuda, R.; Hasegawa, J.; Ishida, M.; Nakajima, T.; Honda, Y.; Kitao, O.; Nakai, H.; Vreven, T.; Throssell, K.; Montgomery Jr., J. A.; Peralta, J. E.; Ogliaro, F.; Bearpark, M. J.; Heyd, J. J.; Brothers, E. N.; Kudin, K. N.; Staroverov, V. N.; Keith, T. A.; Kobayashi, R.; Normand, J.; Raghavachari, K.; Rendell, A. P.; Burant, J. C.; Iyengar, S. S.; Tomasi, J.; Cossi, M.; Millam, J. M.; Klene, M.; Adamo, C.; Cammi, R.; Ochterski, J. W.; Martin, R. L.; Morokuma, K.; Farkas, O.; Foresman, J. B.; Fox, D. J. Gaussian 16 Rev. A.03; Gaussian, Inc.: Wallingford, CT, USA, 2016.

3. Zhang, J.; Yang, C.; Zhang, R.; Chen, R.; Zhang, Z.; Zhang, W.; Peng, S. H.; Chen, X.; Liu, G.; Hsu, C. S.; Lee, C. S. Biocompatible D-A Semiconducting Polymer Nanoparticle with Light-Harvesting Unit for Highly Effective Photoacoustic Imaging Guided Photothermal Therapy. Adv. Funct. Mater. 2017, 27 (13), 1605094. 